\title{
El horizonte europeo de la guerra de España en Cuba (1896-1898)*
}

\author{
Cristóbal Robles Muñoz. \\ Instituto de Historia, Centro de Humanidades, \\ CSIC. Madrid
}

Con escasas excepciones, la opinión española, parlamento y prensa, desconoció la vertiente internacional de la guerra de Cuba. Era ya en 1895 un conflicto colonial no un enfrentamiento civil. Por eso las reformas llegaron tarde. Se olvidó que, con alianzas o sin ellas, España sólo podría contar eficazmente con otras naciones si la situación internacional lo consentía. No era así en los años noventa. Cánovas lo sabía y lo insinuó en las Cortes las pocas veces en las que se trató de la cuestión. Este trabajo examina las relaciones entre las potencias europeas y su política en el Mediterráneo, los Balcanes, Extremo Oriente y el Caribe.

En crisis las alianzas existentes en Europa, salvo la recién formada entente franco-rusa, el gobierno conservador, presidido por Cánovas desde 1895, trató de definir su política internacional: amistad con Italia y el Reino Unido, pero sin ampliar el compromiso más allá de lo que se firmó en marzo de 1887: defender el statu quo en Marruecos. Tener las manos libres desarmaba cualquier recelo o sentimiento hostil de Francia. Cuando la amenaza de Estados Unidos se sintió cerca, a la vista de su posición en el litigio entre Venezuela e Inglaterra, el ministro de Estado, presionado por los amigos de Italia, especialmente por Austria-Hungría, asoció la renovación de los acuerdos firmados en mayo de 1887 y renovados en 1891, con la obligación de auxiliar a España en el caso de una guerra con los norteamericanos.

Desconocemos si se trató de una maniobra para eludir un compromiso reforzado quizás con la presión de la Reina Regente. ${ }^{1} \mathrm{O}$ hubo un error

\section{* Siglas:}

AAE CP: Archive du Ministère des Affaires Étrangères, Correspondence Politique, volume, Paris. AAE NS Espagne: Archive du Ministère des Affaires Étrangères, Nouvelle Série, volume, Paris. AMAE H: Archivo del Ministerio de Asuntos Exteriores. Sección Histórica, legajo, Madrid. ASD SP P: Archivio Storico Diplomatico, Serie politica P pacco, Roma.

ASD DDS: Documenti Diplomatici a Stampa, serie y volumen, textos impresos bajo la rúbica "confidenziale".

PS97-1155 de la DGICYT.

1 Hay que señalar que la documentación sobre la negociación de estos acuerdos se halla casi en su totalidad en la sección secreta del AGP. La intervención de la Reina Regente durante la crisis del 98 queda patente. Companys, Julián: España en 1898: entre la diplomacia y la guerra, Madrid, 1992; Robles, Cristóbal: 1898: Diplomacia y Opinión, Madrid, 1991. 
de cálculo. ${ }^{2}$ Su condición de nación mediterránea y el tener territorios vecinos de los Estados Unidos creó una contradicción insalvable. ${ }^{3}$ España quedó sola. En la emoción de la derrota, vio agravio en lo que fue debate jurídico y una negociación entre partes con intereses contrapuestos. ${ }^{4}$

Esa representación pesó en la opinión más que en la sociedad española. ${ }^{5}$ Perduró 6 y creó un imaginario que, como todos, termina asociado a la violencia y justificándola irracionalmente.

\section{Crisis cubana y solidaridad europea}

A comienzos del verano de 1896 una escuadra francesa visitó España. Tuvo un buena acogida. La diplomacia francesa utilizaba estas demostraciones de poderío militar como un instrumento. Los españoles hablaron de amistad entre los dos vecinos. En el horizonte y como razón, la amenaza de guerra con Estados Unidos. Esta reacción, repetida en Barcelona donde estuvo una agrupación musical militar francesa, brotaba quizás de la necesidad de creer que la República estaría al lado de España en caso de conflicto con los norteamericanos.

2 Una visión de la política del último gobierno presidido por Cánovas, O’Donnell, Carlos, duque de Tetuán: Apuntes para la defensa de la política internacional y gestión diplomática del Gobierno Liberal-Conservador desde el 28 de marzo de 1895 al 29 de septiembre de 1897, Madrid, 1902.

3 El interés de Estados Unidos sobre Puerto Rico y la dimensión internacional de la posesión de la isla como una base naval en el Caribe, Estades Font, María Eugenia: La presencia militar de Estados Unidos en Puerto Rico 1898-1918. Intereses estratégicos y dominación colonial, Río Piedras, 1988, págs 39, 43, 54, 57-58, 60-76 y 207.

4 Queda constancia de que así fue en las actas de las sesiones de la comisión que negoció la paz. Documentos presentados a las Cortes en la Legislatura de 1898 por el ministro de Estado (duque de Almodóvar del Río). Conferencia de París, Madrid, 1899. El peso de lo jurídico en la negociación quedó patente en algunos hechos. Los norteamericanos no consintieron que el pago de la Deuda Cubana hipotecara los recursos a disposición del gobierno que inaugurara la independencia. Estados Unidos se obligaba a garantizar el cumplimiento de lo pactado, en el caso de que no lo hiciera Cuba. Ese fue el origen jurídico de la "enmienda Platt". Una versión de lo sucedido en París, Montero Ríos, Eugenio: El Tratado de París, Madrid, 1904. El autor presidió la comisión española.

5 La sociedad española supo remontar las consecuencias de la guerra. Saldó sus deudas. Restableció el equilibrio presupuestario, y el país pudo emprender una política internacional más activa. Ese fue el balance de la gestión de Francisco Silvela las dos veces que presidió el gobierno.

6 Esa constante ha hallado una expresión dolorida y brillante en Laín Entralgo que dictamina como enfermedad española un "darwinismo invertido", es decir, la selección siempre de los peores para sobrevivir y tener éxito: Descargo de conciencia, 1936-1960, Barcelona, 1976. Posiblemente el mejor resultado del I Centenario del 98 ha sido la revisión de lo que fue aquel final de siglo. 
Cuba estaba en el centro de la vida pública española. Para octubre se pensaba enviar a la isla otros 40.000 soldados. Con ellos se alcanzaría la cifra de 170.000 .

El gobierno había recibido una autorización especial, unánimemente votada, autorizando los gastos extraordinarios que los ministerios de Guerra y Marina tuvieran que afrontar "con motivo de la actual alteración del orden público" en Cuba. ${ }^{7}$

Estos dos hechos y el clima emocional en que se producen resumen el estado de ánimo de la opinión y de los políticos a poco más de un año del inicio de la guerra en Cuba.

Preocupaba al embajador italiano en Madrid el incremento de la influencia francesa en España, que no había renovado el año anterior sus acuerdos mediterráneos con Italia. Esta, a su vez, reorientaba su política exterior tras la formación del gobierno presidido por Antonio Starabba, marqués di Rudinì. ${ }^{8}$

El recibimiento que tuvo la flota francesa era un mensaje al gobierno: había que acabar con el aislamiento. ${ }^{9}$ Otros dijeron que el gobierno no se debería dejar arrastrar por esa ola de manifestaciones. ${ }^{10} \mathrm{El}$ ministro francés de Asuntos Exteriores, Gabriel Hanotaux, reconoció ante el embajador de España en París, duque de Mandas, que nunca habían sido mejores las relaciones entre los dos países. Y eso sucedía cuando parecían aproximarse Roma y París. ${ }^{11}$ Marruecos era un asunto excluido en la negociación con

7 “(Il parlamento) tutto concede che gli si chiegga: uomini e denaro". ASD SP 71 1896, 436/140 Renzis-Onorato Caetani, 28 de junio de 1896. Renzis aseguraba que los gastos mensuales que ocasionaba la guerra en Cuba ascendían a 25 millones de francos, es decir, unos 300 millones al año. La noticia se la dio el duque de Tetuán, ibídem, 6/3, 4 de enero de 1897. Roma, 1976.

8 Belardinelli, Mario: Un esperimento liberal-conservatore: i governi di Rudinì (1896-1898),

El gobierno de di Rudinì significó, tras la derrota de Adua, un intento de recuperar las fuerzas que apoyaban la monarquía con una política liberal-conservadora. Es un conservadurismo innovador. Esta tendencia tuvo éxito en las elecciones de 1897. La abstención de los católicos y la presencia de los socialistas en las protestas populares provocaron medidas contra los subversivos, entre los que se contaba a los "clericales".

9 Esa fue la interpretación de los diarios republicanos, El Liberal y El País. El pueblo "indique surtout à son gouvernement que l'Espagne ne doit pas rester isolée et doit faire preuve, en présence de l'insurrection cubaine, de solidarité européenne!". AAE CP Espagne 928 y 929, 104 y 106 L. Descos-Hanotaux, 27 de junio y 2 de julio de 1896, págs 380-381 y 10-13.

10 La Correspondencia de España advertía el 24 de junio, que esas expresiones populares, que revelaban una "constante fraternidad" con Francia, pudieran causar molestia o agravio a Italia, Alemania, Inglaterra, Austria y Rusia, "con los cuales estamos en las más perfectas relaciones”. Cuando era muy probable "un conflicto político" con Estados Unidos, no había que crear si quiera la apariencia de que se pedía protección a los otros. Las alianzas han de forjarse siempre mediante la negociación. No deben ser fruto de "acelaramientos irreflexivos".

11 AAE NS Espagne 36, Note du Ministre, 5 de julio, págs 3-6. 
Italia. Francia y España coincidían en la defensa del statu quo. Si alguna vez hubiera que pactar con alguien, Francia solo lo haría con España. ${ }^{12}$

Francia temía un acuerdo entre Italia y el Reino Unido, que afectaría a dos puntos vitales en el Mediterráneo: Egipto y Marruecos. El discurso del ministro de Asuntos Exteriores, Onorato Caetani, duque de Sermoneta, excluía ese posible acuerdo.

La declaración, hecha al debatirse el presupuesto del ministerio, fijaba el marco en el que iba a situarse su gestión. Italia seguiría siendo leal a la Triple Alianza, en cuya política confiaba sin reservas. Sus objetivos a nadie deberían causar miedo.

Italia tendría relaciones cordiales con las otras potencias. En San Petersburgo acababa de ser muy bien recibido el Príncipe de Nápoles. Con Inglaterra había una relación que unía intereses, sentimientos y tradiciones. ${ }^{13}$ La cuestión de Oriente reclamaba, como sucedió años antes, el "concierto europeo". ${ }^{14}$ Italia defendería en los Balcanes el statu quo, respetando el principio de las nacionalidades y los límites fijados por los tratados. ${ }^{15}$ En cambio, el objetivo de Francia fue impedir la hegemonía de Inglaterra en el imperio turco. ${ }^{16}$

12 "Todo el concurso indirecto, pero eficaz, que Francia pueda darnos, nos lo dará, tales como las emisiones colocadas en París y cosas análogas". AMAE H 1533, reservado 198 Mandas-Tetuán, 2 de julio. Una breve biografía del duque de Mandas, redactada por Urquijo Goitia, Miguel: Diccionario biográfico de los parlamentarios de Vasconia (1808-1872), Vitoria, 1993, págs. 527-534.

13 'Nos rapports amicaux avec l'Angleterre sont à nos yeux le complément naturel de la Triple Alliance et tirent leur efficacité de ce fait qu'ils unissent des intérêts mutuels à des sentiments réciproques et traditionnels".

14 La existencia del "concierto europeo" favoreció la unidad de Italia. Logró Cavour ganarse un lugar en la Europa posterior a 1815, apelando alternativamente a la "Europa de las nacionalidades" y la Europa de los Congresos entre 1856 y 1867 . Esos dos horizontes los mantendría respecto a la cuestión de Oriente. Cuando dejó de existir el concierto, Italia pudo ingresar entre las grandes potencias. Cialdea, Basilio: L'Italia nel concerto europeo (1861-1867), Torino, 1966; Langhorne, R.: The Collapse of the Concert of Europe. International Politic 1890-1914, London, 1981; Bosworth, R.J.B.: Italy, the last of the great Powers: Italian Foreing Policy before firts World War, London, 1979. Usó antes esta misma imagen Decleva, E.: L'Italia e la política internazionale dal 1870 al 1914. L'ultima fra le grandi potenze, Milano, 1974.

15 Fue esta una tesis del Risorgimento. La fijó en 1852 Pasquale Stanislao Mancini en su obra Della nazionalità come fondamento del diritto delle genti, editada por Erik Jayme, Torino, 1994. Mancini, que enseñó Derecho Internacional en esta universidad desde 1851, y luego en Roma, fue nombrado en 1873 presidente del Instituto de Derecho Internacional, de Ginebra. Ministro de Asuntos Exteriores desde mayo de 1881 hasta junio de 1885, supo acomodar sus ideas a su posición política, llevando adelante la alianza con Austria-Hungría y Alemania e iniciando la política colonial con la toma de Assab. Fue éste el motivo que provocó su dimisión.

16 "Lettres de Paul Cambon, ambassadeur de France, au Président de la République Félix Faure (1895-1899)": Revue d'Histoire Diplomatique, 68, París, 1954, págs 189-201. Cartas enviadas desde Constantinopla entre el 21 de enero de 1895 y diciembre de 1896. 
El imperio otomano debería reconocer a Bulgaria su autonomía en las relaciones con otros Estados. Había una cooperación con Egipto para que, mediante reformas, se restableciera la paz en Creta, sin necesidad de emplear medidas militares.

Los conflictos de 1889 acabaron con la autonomía restringida que funcionaba en la isla. Regresó la mala administración y los abusos de los funcionarios. En 1895 los musulmanes atacaron a los cristianos. Un año después, tuvo lugar la demostración naval de las potencias. Y en la primavera de 1897, la guerra greco-turca. Tras ser derrotada Grecia, se dividió la isla en 5 sectores bajo la protección de Rusia, Inglaterra, Italia y Francia. La capital quedó bajo la administración de las cuatro potencias. En 1898, la matanza de Candia, con la pasividad cómplice de los 4.000 soldados turcos, provocó una rebelión que acabó con un acuerdo, patrocinado por los cuatro cónsules. Una Asamblea votó el 27 de abril de 1899 una constitución, que reconocía la presencia de un musulmán en el gobierno. No se logró esto último. La población musulmana descendió de 85.000 a 33.000 en el censo de 1900. ${ }^{17}$

En el Mediterráneo, aunque no se renovara el tratado comercial con Túnez el 29 de septiembre de 1896, Italia continuaba en posesión de unos derechos..$^{18}$ El futuro de Tripolitania y su estatuto dependía de que se conservara la integridad del imperio turco. El gobierno de Roma vigilaría para que, si se llegara a producirse su fragmentación, no fuera perjuicio de Italia. ${ }^{19}$

En las relaciones franco-italianas, no se había pasado de los preliminares. Había viajado a París un comisionado especial del gobierno.$^{20} \mathrm{Ni}$ siquiera ese dato significaba una novedad. El presidente del consejo, Antonio di Rudinì, había declarado que la pertenencia a la Triple Alianza no impedía unas buenas relaciones con Francia y Rusia. Esa era la posición

17 Ganiage, Jean: "Les affaires de Crète (1895-1899)": Revue d'Histoire Diplomatique, 88, París, 1974, págs. 88-111. Sobre Creta volvería a intervenir en la Cámara Visconti Venosta el 9 de abril de 1897, respondiendo al diputado Imbriani.

18 Para el impacto económico y social de la implantación del protectorado, Martin, J.-F.: Histoire de la Tunisie contemporaine, de Ferry a Bourguiba, 1881-1956, Paris, 1993.

19 El discurso, que había sido revisado y aprobado en el consejo de ministros, fue aplaudido por la opinión. Había afirmaciones claras y se creía en la sinceridad del duque de Sermoneta. AMAE H 1622, 145 Conde de Benomar-Duque de Tetuán, 1 de julio de 1896, En el debate intervino Alessandro Fortis. El diputado, antiguo mazziniano, había evolucionado hacia la izquierda legalista. Cooperó con Crispi en el ministerio del Interior. Fue ministro de Agricultura, Industria y Comercio con el general Pelloux desde junio de 1898. Salió del gobierno y regresó al poder como sucesor de Giolitti en la presidencia del consejo, desde el 28 de marzo de 1905 hasta el 8 de febrero del año siguiente.

20 Con su voluntad de mejorarlas el duque de Sermoneta demostraba que el nuevo gobierno pondría en primer término los intereses del país. AMAE H 1622, 149 Benomar-Tetuán, 3 de julio. 
que Goluchoswki, el canciller de Austria-Hungría, acababa de manifestar ante las delegaciones del imperio. ${ }^{21}$

La crisis del gobierno provocó el relevo de Caetani por Emilio Visconti Venosta en Asuntos Exteriores. ${ }^{22}$ Estuvo en el ministerio hasta el 2 de junio de 1898. Lo sustituyó Raffaele Capelli, ${ }^{23}$ por un desacuerdo político con di Rudinì en torno a la ley para las elecciones administrativas. ${ }^{24}$

Sus objetivos al aceptar la cartera de Exteriores eran Francia y Rusia. Con esta, uno de los medios, aumentar las relaciones entre las dos casas reales. Pensó en un encuentro del zar Nicolás II con el conde de Turín durante las maniobras militares en Breslavia..$^{25}$ El proyecto llegaba tarde. ${ }^{26}$ Humberto I no quería que se excluyera a Italia en el recorrido que el zar haría por otras naciones de Europa. No pudo ser, por el compromiso que tenía de estar en San Petersburgo el 20 de octubre, aniversario de la muerte de su padre. ${ }^{27}$

21 La agencia Stefani publicó en la tarde del 3 de julio de 1896 una nota oficiosa: las declaraciones de di Rudinì y de Caetani habían tenido una excelente acogida en Berlín, Viena y Londres. Fue un acto oportuno, pero no podría superar la desconfianza, que existía aún, respecto a la nueva orientación de la política exterior italiana tras la dimisión de Francesco Crispi y la sustitución de Antonio Blanc en el ministerio de Asuntos Exteriores. AMAE H 1622, 148 Benomar-Tetuán, 3 de julio. Respondía el embajador en Roma a la Real Orden del 24 de junio, en la que le remitían un despacho del duque de Mandas, embajador en París, con fecha del 18 de ese mes.

22 Propuesta de di Rudinì, 13 de julio, aceptación y comunicación a los representantes de Italia, 17 y 20 de julio, Documenti Diplomatici Italiani, serie terza, volumen primo, Roma, 1953, pág. 89. Sobre Visconti, Chabod, Federico: Storia della politica estera italiana dal 1870 al 1896. Volume primo: le premesse, Bari, 1951, págs. 573-599, y Cantalucio, F.: La politica estera di E. Visconti-Venosta, Firenze, 1940.

23 La comunicación a los embajadores y agentes diplomáticos de Italia en el extranjero, telegramas 1335 y 1336, 2 de junio de 1898, Documenti Diplomatici Italiani, serie terza, volumen secondo, Roma, 1958, pág. 335.

24 Los motivos de la dimisión, mantenidos en secreto hasta que el gobierno regresara de Turín a Roma, carta particular Visconti-di Rudinì, 28 de abril de 1898. El presidente del consejo también se consideraba dimitido. Carta particular, di Rudinì-Visconti, 29 de abril, ibídem, págs 311 y 315 . Cuando se formó el nuevo gobierno presidido también por di Rudinì, Alemania esperaba que Raffaele Capelli continuara la política de Visconti Venosta. La inestabilidad de los ministerios se explicaba por la índole parlamentaria de la monarquía italiana. $769 / 329$ Lanza-Cappelli, 8 de junio, ibídem, págs. 341-342. El 30 de junio se formó un gobierno presidido por el general Luigi Gerolamo Pelloux. Se encargó de Asuntos Exteriores Felice Napoleone Canevaro.

25 Carta confidencial Visconti-Nigra, 10 de agosto de 1896. Insistió en un telegrama sin número 11 de agosto, Documenti Diplomatici Italiani, serie terza, volumen primo, Roma, 1953, págs. 111 y 112 .

26 Telegrama sin número Nigra-Visconti, 16 de agosto, ibídem, pág. 118. Por un telegrama personal del ministro, enviado el día siguiente, sabemos que el rey se negó a solicitar esa entrevista, pero aprobó la idea de que Nigra comenzase a gestionar la posible visita del zar a Italia.

27 Telegrama personal Visconti-Nigra, 26 de agosto, y telegrama personal Nigra-Visconti, 27 de agosto, ibídem, pág. 128. Los proyectos para que fuera posible en 1897, carta confidencial NigraVisconti, 28 de agosto, ibídem, págs. 130-131. 
Después de la estancia de Nicolás II a Breslavia, el príncipe Hohenlohe y el barón Marshall informaron al embajador Lanza de la política de Rusia. Se mantenía la amistad con Alemania. ${ }^{28}$ Desconfiaba de Inglaterra, que suscitaría cuestiones en la Europa Oriental para apartar de Asia la atención de los rusos. El viaje a París fue una necesidad política, cumplida con patente desgana. El zar, por motivos religiosos, deseaba que Italia y el negus Menelik firmaran la paz. ${ }^{29}$

\section{El Tuat, Cassala y los pactos en Europa}

La prensa de París anunciaba el 12 de agosto de 1896 que el consejo de ministros, al que asistiría el presidente de la república, abordaría un informe del ministro de la Guerra con los planes para ocupar el Tuat y Guerara. Para comprender ese paso había que tener en cuenta estos dos datos: las acciones francesas contra los tuaregs y el consentimiento de Inglaterra. Eran otros tiempos. Hasta entonces España, Italia y el Reino Unido habían apoyado al sultán de Marruecos para que resistiera la presión de Francia. Ahora Londres se desentendía. ${ }^{30}$

El comunicado de la agencia Havas no mencionaba que el consejo de ministros del 14 de agosto hubiese tratado el asunto. Podría significar que no estuviera en el orden del día, que nada se hubiera determinado o no se hubiera informado al público. ${ }^{31}$

Uno de los diarios que más había alentado la expedición, cambió de tono, anunciando que el gobierno no se arriesgaba a emprenderla. Había que dejarla hasta resolver la cuestión del Gadamés. ${ }^{32}$

En octubre la prensa de Argelia daba por hecha la expedición. Se dijo que Mohamed Torres había propuesto un arbitraje al ministro de Francia en Tánger. ${ }^{33}$

28 Pese a esa afirmación, la prensa francesa, tras la visita de Nicolás II a Francia, habló de la existencia de una alianza. En Alemania se juzgaba esa reacción como una prueba de que el revanchismo continuaba vivo en Francia. 1414/483 Lanza-Visconti, 15 de noviembre, ibídem, págs. 175-176.

29 Telegrama reservado 2108 Lanza-Visconti, 12 de septiembre, ibídem, pág. 142.

30 ASD DDS XL/11, 2820/747 G. Tornielli-Visconti Venosta, 12 de agosto de 1896, pág. 21.

31 La Depêche Algérienne publicó un articulo en el que advertía del riesgo de emprender una acción sin contar con los recursos que asegurasen su éxito. No habría que atender las prisas de algunos elementos colonialistas, ibídem, 2869/760 G. Tornielli-Visconti Venosta, 16 de agosto, pág. 25.

32 ASD AP P 201, 2131/297 Cónsul en Argelia-Visconti, 26 de agosto.

33 ASD DDS XL/11 571/108 G. Malmusi-Visconti Venosta, 12 de octubre, pág. 33. Inmediatamente se pidió información al embajador en París. 
La expedición penetró por el Sur de Orán en dos puntos. Iban unos 2.000 hombres. Habían caído las dudas. En agosto se creía que, sin poseer también Gadamés, imposible de controlar entonces, el Tuat nada valía para llegar hasta el lago Tchad. ${ }^{34}$ Sin embargo el ministro de Exteriores francés había asegurado varias veces al embajador de Italia que no existían planes en relación con el hinterland tunecino.

Aunque el motivo de la expedición estuviera localizado, no podría ignorarse que formaba parte de un proyecto más amplio, formulado después de obtener que Inglaterra reconociera la influencia francesa en una extensa zona del Sahara. Aquel descuido impedía actuar en ella, según Lord Salisbury. ${ }^{35}$

Había mejorado la postura francesa hacia Alemania. A través de Rusia, se hizo saber a París que en el gobierno alemán quitaba trascendencia a los escritos periodísticos. Preocupaba sobre todo la actitud francesa hacia Italia. Estaba provocando dificultades comerciales, "non basate sul vero interesse economico, ma collo scopo di distaccarla dalla Triplice Alleanza". ${ }^{36}$

Tensas las relaciones con Londres, no podría creerse que Alemania se volviera hacia Rusia y confiara en ella. En Berlín estaban a la espera de la orientación de la políticas rusa. Había que designar un nuevo ministro de Asuntos Exteriores, sustituto del príncipe Lobanoff para despejar la incógnita que planteaban las divergentes tendencias que presionaban a Nicolás II. ${ }^{37}$

Mientras, Guillermo II parecía favorecer las buenas relaciones con Reino Unido. Era una ilusión. Porque las diferencias comerciales y coloniales no las solucionan los contactos personales. ${ }^{38}$

34 Italia no podría quedar pasiva si se efectuara esa expansión hacia Gadamès y el hinterland tripolitano. ASD DDS XL/11, 43010/1076 Visconti Venosta-Tornielli, 17 de noviembre, pág. 41.

35 ASD DDS XL/11, 3739/970 G. Tornielli-Visconti Venosta, 28 de ocubre, págs. 35-36. Las causas del retraso, ibídem, 3766/977 y 3800/988 G. Tornielli-Visconti Venosta, 4 y 8 de noviembre, págs. 37-39.

36 Telegrama 2217 Lanza-Visconti, 25 de septiembre de 1896, Documenti Diplomatici Italiani, serie terza, volume primo, Roma, 1953, pág. 156.

37 Un juicio sobre Muravieff, nuevo ministro de Asuntos Exteriores, telegrama 70 LanzaVisconti, 11 de enero de 1897. Confirmación del nombramiento de Muravieff, telegrama 105 MaffeiVisconti, San Petersburgo 13 de enero de 1897, Documenti Diplomatici Italiani, serie terza, volume primo, Roma, 1953, pág. 245. La promesa de buenas relaciones de Rusia con I. entrevista de Muravieff con Lanza, telegrama 306 Lanza-Visconti, 31 de enero, ibídem, pág. 251.

38 Carta particular Lanza-Visconti, 10 de enero, Documenti Diplomatici Italiani, serie terza, volume primo, Roma, 1053, págs. 243-244. En una nota al documento de Lanza, Visconti dice que la política alemana no cambiará mientras permanezca Holstein, que ya estaba en la sección política y personal de Asuntos Exteriores en tiempos de Bismarck y fue consejero de von Caprivi, Hohenlohe y Marshall. Una audiencia con Guillermo II, que expuso sus puntos sobre la situación internacional y sobre el problema turco, telegrama reservado 197 Lanza-Visconti, 22 de enero, ibídem, pág. 247. 
Por encargo de Visconti Venosta, el secretario de la legación en Londres se informó sobre la existencia de un acuerdo del Reino Unido con Francia y Rusia.

Thomas Henry Sanderson, subsecretario permanente del Foreing Office, dijo que nada le había comunicado desde Balmoral Salisbury. Este consiguió disipar la imagen de "egoísmo" de los gobiernos ingleses con su política en Oriente ${ }^{39}$ Haber destruido algunos malentendidos era ya un éxito.

Si las condiciones no le resultaran onerosas, Londres podría romper su tradición de no compromiso con alguna potencia o grupo. En esa dirección podría empujarle la aversión política hacia Alemania y las diferencias comerciales con ella. Otro factor decisivo sería el coste del aislamiento en una Europa dividida en dos campos..$^{40}$

En enero de 1897 se comunicó a Lanza, embajador en Berlín, que Alemania deseaba conservar sólida la Triple Alianza. Era previsible que, si el Reino Unido quería conservar su aislamiento, se inclinaría hacia el este buscando la aportación de Rusia. De momento no intentaría enemistarse con Alemania y separarse de la Triple Alianza. Berlín pediría a sus aliados cautela en sus relaciones con Londres. ${ }^{41}$

Renovado el pacto, dejando intacta la situación en lo que afectaba a Reino Unido y Alemania, ésta quería ganarse la amistad de Rusia para que la alianza franco-rusa no tuviera una orientación antialemana. Esos días, la prensa reveló la existencia de un acuerdo entre Alemania y Rusia. Fue una maniobra de la Hamburger Nachrichten, que inspiraba Bismarck.

Cuando en 1890 llegaron al ministerio de Asuntos Exteriores Caprivi y Marshall, quisieron denunciar ese pacto, porque les parecía una complicación política y era además una deslealtad hacia los aliados. En esa fecha se notificó a Austria que no existía acuerdo alguno con Rusia. Nada podría decirse, ya que había una obligación de guardar secreto, incluso después de cesar el acuerdo. Era un pacto de neutralidad. La comunicación de

39 Los conservadores llegaron tras un gobierno presidido por Rosebery. Secretario del Foreing Office en 1886 y de 1892 a 1894, y primer ministro 1894-5, tras Gladstone, juzgaba a Francia el principal enemigo en el Mediterráneo y África. Temía la alianza franco-rusa y pensaba que Alemania sería su contrapeso, reforzada por sus dos aliados, Austria-Hungría e Italia. Rosebery quiso apoyarse en Alemania, pero sin asumir compromisos de aliado, como deseaba Guillermo II. Martel, Gordon: Imperial diplomacy. Rosebery and the failure of foreing policy, Kingston et Montreal, 1986.

40 Telegrama 1716 Visconti-Costa, 9 de octubre de 1896. Respuesta confidencial 565/244 Costa-Visconti, 13 de octubre, Documenti Diplomatici Italiani, págs. 168 y 173-174.

41 Uno de los motivos de la pasividad alemana en el problema turco era su deseo de no favorecer al Reino Unido, carta particular Lanza-Visconti, 10 de enero, Documenti Diplomatici Italiani, págs. 242-243. 
Marshall pretendía disipar dudas sobre la fidelidad del gobierno alemán a sus aliados. ${ }^{42}$

El Reino Unido no sacrificaría su posición en el Mediterráneo. En esas circunstancias, Alemania no daría un paso más. Italia, que quiso ser el lazo de unión entre el Reino Unido y la Triple Alianza, no sacó provecho alguno. Lanza creía que convenía a Italia quedar libre de compromisos con los ingleses en Cassala para poder conducirse sin otra preocupación que su conveniencia en el Mediterráneo. ${ }^{43}$ Se decidió abandonar Cassala y se comunicó al Reino Unido, ${ }^{44}$ anunciando que esperarían a que terminaran las operaciones en Sudán. ${ }^{45}$

\section{Acuerdos o desquite entre adversarios}

No terminaban de encarrilarse las relaciones de Francia con Italia. Así quedó patente en los discursos del presidente del Consejo, el marqués di Rudinì, y del ministro de Exteriores, duque de Sermoneta, el 1 de julio en la Cámara de Diputados de Roma. Ambos sostuvieron que los derechos reconocidos a su país por el bey de Túnez no caducaban al crearse el protectorado francés. Por parte francesa, el gobierno de Félix Méline estaba dispuesto a hacer concesiones comerciales, si se llegaba a un arreglo en la negociación pendiente sobre Túnez. ${ }^{46}$

42 Telegramas 2457 y 2472 Lanza-Visconti, 28 y 31 de octubre de 1896, ibídem, págs. 195 y 197. El malestar de Guillermo II y del canciller Hohenlohe por las revelaciones hechas por la prensa adicta a Bismarck, telegrama 2475 Lanza-Viconti, 1 de noviembre, ibídem, págs. 189-199. El gobierno declaró en el Reichstag que Alemania era fiel a la Triple Alianza y mantendría su amistad con Rusia. Telegrama 2576 Lanza-Visconti, 16 de noviembre, ibídem, págs. 206-207.

43 Estas reflexiones las hizo Lanza tras conversar el 19 de octubre con el embajador inglés, preocupado por las derivaciones que podría tener la irritación inglesa hacia Alemania. Lanza envía como anexo la traducción de un artículo de la Deutsche Wochenblatt sobre la visita de Nicolás II a París. El periódico anunciaba la unión de las potencias continentales contra Inglaterra y Rusia. Confidencial 1444/494 Lanza-Visconti, 20 de octubre de 1896, ibídem, págs. 182-184. Tres días más tarde, el embajador en París transmitía a Visconti los comentarios franceses que patrocinaban un acercamiento a Italia y Rusia. Reservado sin número Tornielli-Visconti, 23 de octubre, ibídem, págs. 185-186.

44 Las instrucciones para llegar a un acuerdo y desalojar Cassala, carta particular reservada Visconti-Ferrero, 5 de febrero de 1897. Respuesta de Ferrero, 7 de febrero, ibídem, págs. 255-258. Ante el silencio de Londres, Ferrero debía comunicar a Salisbury que Italia evacuaría Cassala. Sólo estaba obligada a avisar antes a Inglaterra. Telegrama 1352 Visconti-Ferrero, 10 de mayo, Documenti Diplomatici Italiani, serie terza, volume secondo, Roma, 1958, pág. 16. Forlani, L.: "La retrocessione di Cassala all'Egitto": Clio IX/3, 1973, págs. 389-415.

45 Telegrama 1992 Ferrero-Visconti, 13 de mayo de 1897. El agradecimiento del gobierno inglés, telegrama 2013, 15 de mayo, Documenti Diplomatici Italiani, págs. 21-25.

46 AMAE H 1533, 301 Mandas-Tetuán, 29 de septiembre. 
Al discutirse el presupuesto de Asuntos Exteriores, los discursos de Nasi, San Giuliano, Damiani, Lucifero y de Caetani preocuparon a Albert Billot. El embajador informó a Hanotaux en un extenso telegrama.

En su encuentro habitual con Tornielli, lamentó el ministro francés que, cuando se trabajaba en un acercamiento entre los dos países, salieran de nuevo a la luz los problemas anteriores y se presentara a Francia como el mayor enemigo de Italia. Aunque el duque de Sermoneta habló correctamente y expresó su amistad hacia Francia, se echaba de menos una réplica al contenido y tono agresivos de los otros oradores. En sus palabras, Gabriel Hanotaux no discutía el derecho de los diputados y de los ministros italianos a formular sus ideas. Lamentaba el efecto que tendría el debate en la prensa francesa dificultando el propósito de llegar a acuerdos en los asuntos pendientes y de crear un clima nuevo entre los dos países. No sería fácil destruir una imagen forjada desde hacía varios años. ${ }^{47}$

En su encuentro con Guillermo II, Nicolás II aseguró que sus acuerdos con Francia no favorecerían el revanchismo de los que deseaban recuperar las dos provincias perdidas en 1870. Era un freno y un desmentido a la impresión que estaban creando los diarios franceses, hablando de una alianza, que permitiría el desquite de su país. ${ }^{48}$

La situación inquietaba en Alemania. Ignorando el verdadero alcance de los vínculos entre franceses y rusos, temía un error de cálculo que pudiera llevar a una guerra. La Kölnische Zeitung, un órgano oficioso, recordaba a la zarina Alejandra su condición de alemana. Debería convencer a Nicolás II de los riesgos que entrañaba una posición tan confusa.

Era motivo de alarma la influencia que la simpatía de los franceses hacia Rusia pudiera tener en las ideas políticas. Ese impacto no debería ignorarlo la clase dirigente de San Petersburgo, comentaba el diario alemán en su revista semanal sobre política exterior. ${ }^{49}$

47 ASD SP P 54 y Documento Diplomatici Italiani... Roma, 1953, págs 85-86, reservado 2276/565 Tornielli-Sermoneta, 2 de julio de 1896. "Delenda est Carthago": Le Temps, 2 juillet, el artículo aconsejaba no otorgar al debate parlamentario más que un valor de oposición a la política interna. Este diario, vinculado a Hanotaux, era una excepción. Esos días afirmó la posibilidad y conveniencia de una relación amistosa con Italia. ASD SP P 54, 2344/584 Tornielli-Sermoneta, 8 de agosto.

48 Un informe sobre la prensa en Francia, sin fecha, con estadística y datos sobre la orientación de los periódicos más importantes, 26 páginas manuscritas, ASD SP P 54, anexo al despacho $3358 / 1234$.

49 ASD SP P 54, 1414/483 Launay-Visconti, 15 de octubre de 1896. Un resumen de la reacción de la prensa en Italia y Alemania sobre la visita y, especialmente, sobre la revista militar en Chalons, "La revue de Chalons": Petit Moniteur, 21 octobre 1896, 1. 
Después de la visita del zar, el general Billot, ministro de la Guerra y persona de ideas moderadas. Como el más antiguo miembro de la Asamblea Nacional y el más antiguo oficial del ejército francés, pronunció un discurso en la inauguración de un monumento a Naillot, président du Conseil de Santé des Armées, nacido en Briey. Apuntó a "notre frontière mutilée". Anunció que el ejército estaría a la altura de su deber "le jour où on aura besoin d'elle (l'armée)".

El conde de Münster, embajador alemán, se quejó.$^{50}$ Gabriel Hanotaux respondió que fue una improvisación y, por eso, no existía una referencia oficial. Pasadas unas pocas semanas, en el debate parlamentario, Billot volvió a hablar de "frontera mutilada". La nación, para defender su independencia, dijo el ministro de la Guerra, necesita un ejército fuerte, porque defender significa poder atacar..$^{51}$

En la Revue de Paris, el diputado italiano Franchetti subrayó la mejora de relaciones entre Francia e Italia. Tuvo eco en la prensa. Hanotaux lo comentó con Tornielli. Habían caído prejuicios y podía hablarse sin suscitar objeciones. Le respondió Georges Clemenceau. Para Hanotaux la amistad entre los dos países, pese a los problemas aún pendientes, debía ser una realidad. Había que salir de la retórica y superar la etapa de Crispi, que no se cansaba de expresar su admiración y afecto hacia Francia, pero actuó con peor voluntad que Bismarck. No ahorró medios para perjudicar a su vecina. ${ }^{52}$

"Francia se consideraba herida por el desarrollo de Italia como nación independiente". Era una tesis de dos diarios italianos, La Tribuna y La Riforma. Ese tipo de afirmaciones suponía vivir de espaldas a la verdad. Lo que separaba a los dos pueblos eran Túnez, aquella decisión que "engager la France dans la grande politique" ${ }^{53}$ y la Triple Alianza.

50 ASD SP P 54, reservado 3638/944 Tornielli-Visconti, 23 de octubre.

51 Comentario a la intervención de Billot en el debate sobre el presupuesto del ministerio de la Guerra el 16 de diciembre. ASD SP P 54, telegrama cifrado 2834 Tornielli-Visconti, 18 de diciembre de 1896.

52 Crispi era un enemigo permanente de Francia. Había neutralizado la buena voluntad de Humberto I. El Rey dijo al embajador Albert Billot: "Les deux pays sont faits pour s'entendre". Dethan, Georges: "Le rapprochement franco-italien après la chute de Crispi juzqu' aux accords Visconti Venosta sur le Maroc et la Tripolitaine (1896-1904), d'après les Archives du Quai d'Orsay", Revue d'Histoire Diplomatique, 70, 1956, págs. 323-339.

53 La decisión tuvo el valor de ir contracorriente. La sociedad "était passive et effacée". La opinión pública, "affolée de paix". Fueron los "oportunistas" y los hombres de negocios los que trabajaron para que Francia ocupara Túnez en 1881. Duroselle Jean-Baptiste y Allain, J.C: "Politique intérieure et politique extérieure sous la IIIè République Française. L'exemple des années 1881-1911", Relations Internationales, 4, 1975, págs. 3-38; Persel, Stuart M.: The French colonial lobby, 18891913, Stanford, 1983. 
En cuanto a Túnez, Jules Ferry actuó en 1881 con doblez y no supo resistir la presión del chauvinismo grosero de los enemigos de la República. Derrochó los recursos del país mientras los alemanes contemplaban esa operación "acampados" en Alsacia y Lorena. Nadie podría tacharlo de patriotero si decía ahora que no había comparación entre la hipócrita brutalidad de la intervención en Túnez y las provocaciones de Crispi, contando con la protección de Alemania y de Inglaterra.

Clemenceau estaba de acuerdo con quienes censuraban la aventura de Túnez, porque condicionó la política continental francesa. ${ }^{54}$ Diez años antes se hubiera ganado la amistad de Italia que, sumada a la de Rusia, habría proporcionado a Francia capacidad para su revancha en el este.

En cuanto a la Triple Alianza, pocos políticos italianos habían protestado de ella. El mismo Franchetti se limitaba a repetir la tesis oficial: su objetivo no era la guerra contra Francia, sino la paz. Francia era una nación mutilada. Cuando Italia quiso recuperar Venecia, los franceses no se enfrentaron a ella. Si un día Francia tratara de hacer lo mismo con Alsacia y Lorena, los italianos serían sus enemigos. Mientras la Triple Alianza subsistiera, las propuestas de acuerdo se reducían a querer recoger al mismo tiempo los frutos de la adhesión de Roma a Berlín y de lo que, en otro tiempo, se llamó la amistad franco-italiana. Eso era una contradicción. "Pour que l'amitié renaisse il faut que les gouvernements tripliciens passent". 55

Tenía Italia simpatías entre los radicales franceses, que deseaban derribar sus instituciones. No habría que mezclar con ellos a los republicanos moderados, en esos momentos en el gobierno. Justificaban aquellos la propaganda contra la monarquía con el pretexto de que así se aproximaban los dos pueblos. Los moderados se reconocían en las palabras de Gabriel Hanotaux: una acción en favor de la república en los países latinos iba en la dirección opuesta a la trazada por el gobierno en política exterior. ${ }^{56}$

54 Sobre los problemas de la presencia francesa véase Barbin, Pierre: "Les débuts difficiles du Protectorat tunisien (mai 1881-avril 1882)", Revue d'Histoire Diplomatique, 85, 1971, págs. 17-64. Sobre esta decisión francesa y el significado que tuvo en la política de Jules Ferry, a partir de noviembre de 1883: Billot, Albert: Jules Ferry. Son oeuvre coloniale et diplomatique, Paris, 1904. Billot fue director de Política en el ministerio, en tiempos de Ferry, desde el 20 de noviembre de 1883 hasta el 5 de abril de 1885. Dethan, Georges: "Albert Billot, directeur des Affaires Politique du Quai d'Orsay au temps de Jules Ferry (1883-1885)", Revue d'Histoire Diplomatique, 89, 1975, págs. 115-126.

55 Clemenceau, Georges: "France et l'Italie", La Justice, 22 octobre 1896, pág. 1. Una extensa biografía suya en Duroselle, Jean Baptiste: Clemenceau, Paris, 1988.

56 ASD SP P 54, reservado 3637/943 Tornielli-Visconti, 23 de octubre de 1896. 


\section{Alianzas y estabilidad política}

La visita de Nicolás II a París se mantuvo en un tono discreto respecto a Alemania. La III República tenía fines pacíficos. Había proporcionado a Francia un período de estabilidad. Era una opción por la paz. Esa había sido su trayectoria. A los franceses les inquietaban dos amenazas: la crisis en el Imperio Turco y la política monetaria de Estados Unidos.

En la cuestión oriental, Francia había optado por favorecer lo que allanase los obstáculos y eliminase riesgos para la paz. Había resistido el empuje de la opinión, horrorizada por la represión contra los armenios. El pueblo francés fue unánime en sus manifestaciones. Nadie tendría fuerza para separarse de ella. Frente a eso, Tornielli señaló el tono de la prensa. Habían creado miedo. Bastaba mirar la marcha de la Bolsa. Hanotaux negó que hubiera renacido la agresividad hacia Alemania. ${ }^{57}$ Apaciguados los ánimos, creía que se debería negociar un acuerdo sobre la base la mutua renuncia a territorios en el norte de África. ${ }^{58} \mathrm{La}$ alusión a Tripolitania era evidente. ${ }^{59}$

El segundo problema era el bimetalismo en Estados Unidos. Ponía en peligro el desarrollo de las relaciones comerciales internacionales y perjudicaba a Europa. Tornielli se extrañó de que, estando en Francia un gobierno presidido por Méline y formando parte del ministerio inglés Balfour, los bimetalistas europeos se quedaran pasivos ante la pretensión norteamericana.

El gobierno francés, según Hanotaux, la juzgaba asunto de primer orden para los intereses de su país, sobre todo los agrícolas. Esta informa-

57 Se ha destacado el pragmatismo de Hanotaux. Quiso evitar enfrentamientos. Intentó frenar la presión del partido colonial para impedir un choque con el Reino Unido. Heggoy, Andrew Alf.: The African policies of Gabriel Hanotaux, University of Georgia Press, 1972. Para el partido colonialista véase Abrams, L. y Miller, D. J.: "Who were French Colonialist? A Reassessment of the Parti Colonial, 1890-1914”, Historical Journal, 19, 1976, págs. 685-752.

58 SD SP P 54 y Documenti Diplomatici Italiani, Roma, 1953, 186-189, reservado 3659/948 y carta personal Tornielli-Visconti, 24 de octubre de 1896. La conveniencia de que los tres aliados marcharan de acuerdo e intercambiaran sus ideas en torno al problema turco, conversación con Bülow, 40106/478 Visconti-Lanza, 27 de octubre, ibídem, págs. 194-195. La Triple Alianza estaba jugando un papel secundario en el problema turco debido a la pasividad de Alemania. Este punto de vista de Visconti, carta particular Lanza-Visconti, 10 de enero de 1897, ibídem, págs. 242-243. Los condicionamientos internos y externos de la actitud francesa ante el problema turco, telegrama 2835 TornielliVisconti, 18 de diciembre de 1896, ibídem, pág. 226.

59 El lugar de Tripolitania en el diseño de la política internacional de Italia, Grange, Daniel G.: "La Méditerránee dans le système politique italien”, Relations Internationales, 60, 1989, págs. 373 386. Es un resumen las conclusiones de la tesis del autor, "L'Italie et la Méditerranée (1896-1911). Recherches sur les fondements d'une politique étrangère". 
ción era importante, porque anunciaba una coincidencia con Italia, admitida por el propio presidente francés.

El ministro de Exteriores transmitió al embajador la noticia de que Italia continuaba en la Triple Alianza. ${ }^{60}$ Fueron frecuentes las declaraciones del ministerio di Rudinì sobre este asunto, debido quizás a la presión de la oposición parlamentaria. Siendo justa la política del gobierno, podría pensarse que Italia tenía dudas respecto a la Triple Alianza. Al mismo tiempo, era imposible evitar que la opinión francesa mantuviera la imagen de que Italia estaba al lado de Alemania consolidando su posesión de la Alsacia y la Lorena. ${ }^{61}$ La intimidad con Austria y el Reino Unido suscitaba sospechas sobre la libertad de acción de Italia. ${ }^{62}$

Mientras se producían estos movimientos, el gobierno conservador de Cánovas abrió las Cortes el 1 de mayo de 1896. Los partidos dinásticos se reestructuraban, según un informe de la embajada de Francia. Podría haber un relevo en su jefatura. Y Francisco Romero Robledo parecía quedar fuera del partido conservador. ${ }^{63}$ Lo mismo podría sucederle a Germán Gamazo en el partido fusionista.

Desde el debate sobre el Discurso de la Corona estaban acercándose Francisco Silvela y Segismundo Moret. Ambos eran partidarios de que España tuviera aliados. Esa decisión no la libraría de su soledad frente a Estados Unidos, pero proporcionaría estabilidad a la política interna ${ }^{64}$ Moret fue consciente de ello en 1887 cuando quiso asociar a España con las potencias monárquicas frente a los manejos de republicanos y carlistas desde Francia ${ }^{65}$ que

60 Telegrama sin número Visconti-Tornielli, 12 de noviembre, ibídem, pág. 204.

61 Carta particular Tornielli-Visconti, 29 de noviembre, ibídem, págs. 214-215.

62 Telegrama privado 506 Tornielli-Visconti, 12 de febrero de 1897, ibídem, pág. 262. El proceso desencadenado a partir de la caída de Crispi iba a suponer revisar la utilidad de la Triple Alianza para Italia tanto en el norte de África, Tripolitania, en África oriental, Abisinia, y en los Balcanes. El acercamiento entre Francia y el Reino Unido tras la crisis de Fachoda y la labor diplomática de Barrère en Roma iba a concluir en los acuerdos franco-italianos de 1902. No fue un camino fácil. La opinión era sensible a esta rectificación política. Los "galófobos" dijeron que Francia deseaba colocar a su país bajo tutela. Decleva, E.: Da Adua a Sarajevo. La politica italiana e la Francia, 1896-1914, Bari, 1970.

63 Romero Robledo, con fuertes intereses en Cuba y a cuyo lado había varios generales, podría desencadenar una reacción peligrosa. Una biografía: Ayala, José: Un político de la Restauración: Romero Robledo, Antequera 1974.

$64 \mathrm{Ni}$ Silvela ni Moret "se font point d'illusions assurement sur l'efficacité d'une intervention européene auprès des États-Unis. Ils savent du reste qu'aucun des systèmes politiques européens, existant à l'heure actuelle, ne saurait avoir d'action à propos des affaires cubaines, mais, au fond de leur pensée, l'alliance qu'ils désirent est beaucoup plus faite pour parer aux necessités de la politique intérieure de la Peninsule qu'a celles de la politique américaine".

65 "Dans cette crise, qu' on prépare, les alliances... auraient pour but de donner un appui solide aux institutions monarchiques et d'imposer la nature et l'étendue des réformes de façon à sauvegarder la situation des hommes d'État espagnol que les entreeprendraient". 
debería tomar nota L. Descos, redactor de este despacho, la existencia de los llamados acuerdos mediterráneos. ${ }^{66}$

Moret deseaba un acuerdo con la Triple Alianza. Y ese proyecto comenzaba a tener eco en el ministro de Estado. ${ }^{67}$ Así se explicaba los movimientos diplomáticos de los últimos meses. ${ }^{68}$

El gobierno se movía entre la contradicción de tener que satisfacer la demanda de Washington introduciendo reformas ${ }^{69} y$ atender a una opinión que descalificaba a los independentistas y pedía su derrota total, como condición previa para revisar la situación política de Cuba. ${ }^{70}$

¿Qué había de verdad en este análisis? A finales de julio, el duque de Tetuán envió un memorándum a las embajadores acreditados ante las potencias europeas. ${ }^{71} \mathrm{~A}$ su regreso de Londres, el embajador inglés en Madrid, H. Drummond Wolff, traía este mensaje. Salisbury aconsejaba la mediación de Rusia. La gestión debía centralizarse en San Petersburgo. ${ }^{72}$ Se conocía la dificultad de que fuera aceptado el encargo. ${ }^{73}$

66 Curato, Federico: La questione marocchina e gli accordi mediterranei italo-spagnuoli del 1987 e del 1891. Volume primo: Sino a la caduta del ministro Moret, Milano, 1961. Volume secondo: Dal giugno 1888 all'agosto 1896, Milano, 1964. García Sanz. Fernando: Historia de las relaciones entre España e Italia. Imágenes, comercio y política (1890-1914), Madrid, 1993, págs. 48-50 y 69-83.

67 “... no estaría tampoco de más aluda a lo que a la Triple Alianza misma interesa que, ante las contingencias y eventualidades del porvenir, España, cuya vitalidad se está demostrando con motivo de la insurrección en Cuba, se vea desembarazada y libre de los compromisos y sacrificios que esta insurrección la obliga”. AMAE H 2416, Duque de Tetuán-Felipe Méndez Vigo, 28 de julio de 1896.

68 La negociación de la renovación de la accesión de España a la Triple Alianza a través de sus acuerdos con Italia, "El Mediterráneo y la diplomacia secreta. España e Italia en 1894", Rassegna Storica del Risorgimento, LXXXIV/III, Roma, 1997, págs. 487-528, y "Entre Francia e Italia. El acuerdo verbal hispano-italiano de 1895", Hispania, 192, Madrid, 1996, págs. 291-322. En estos dos trabajos recojo la bibliografía.

69 He tratado de esto en varios trabajos anteriores: "Triunfar en Washington. España ante Baire", Anuario de Estudios Americanos, XLIX, Sevilla, 1992, págs. 563-584; "Reformas políticas y pacificación militar en Cuba", Hispania, 180, 1992, págs. 173-234; "Negociar la paz en Cuba", Revista de Indias, 198, 1993, págs. 493-527.

70 AAE CP Espagne 929, 117 L. Descos-Hanotaux, 20 de julio de 1896, págs. 80-83. La postura del gobierno español fue alabada por The Standard. El 11 de agosto se subrayaba el respeto al presidente Cleveland y a los ciudadanos norteamericanos, a quienes sólo se pedía que observaran sus propias leyes de neutralidad. Vencida la insurrección, se reformaría la administración colonial.

71 Se reunieron en París funcionarios españoles para asegurar la confidencialidad del texto. AMAE H 2416, telegrama cifrado Tetuán-embajadores, 6 y 8 de agosto de 1896.

72 Esa propuesta, sugerida también por el barón de Renzis, embajador de Italia en Madrid, tenía a su favor las buenas relaciones del gobierno ruso con Estados Unidos. Se pedía el apoyo alemán, pues estaba prevista en agosto una reunión de Guillermo II con Nicolás II. Renzis confiaba que Francia ejerciera ante el gobierno del Zar sus buenos oficios. AMAE H 2416, Tetuán-Benomar, 28 de julio. Al barón Marshall causó buena impresión la conducta de España, ibídem, telegrama cifrado y 145 Méndez Vigo-Tetuán, 16 y 18 de agosto.

73 Se pediría a Francisco José de Austria que interviniera ante el zar. El embajador ruso en Madrid era portador de una carta personal de la Regente para Nicolás II. AMAE H 2416, Tetuán-conde de Villagonzalo, 28 de julio. 
El embajador en Londres debería, al presentar el documento, "acentuar de palabra su expresión, robusteciendo los conceptos y argumentos para poner de relieve la conducta de los Estados Unidos" y "explicar lo mucho que a la Monarquía en España y a la Regencia, así como al principio monárquico en general, interesa y puede afectar las consecuencias de la insurrección en Cuba y mayormente, las de un conflicto internacional con los Estados Unidos...”. España se vería forzada a ir hasta ese límite, porque, no hacerlo, sería proporcionar argumentos a los partidos revolucionarios. ${ }^{74}$ Para vencer en Cuba, concentraría en la isla 200.000 soldados.

Aunque se suspendió la entrega del documento, se ordenó que se guardara para usarlo si fuera necesario. ${ }^{75}$ Una extensa entrevista entre el ministro de Estados Unidos en Madrid y el duque de Tetuán cambió el clima. ${ }^{76}$ Había que suavizar asperezas y cualquier gesto para evitar que, al conocer la existencia del memorándum, se disgustara el secretario de Estado norteamericano. ${ }^{77}$ Decidido no enviar el memorándum, tras la proclama del presidente Cleveland, Visconti Venosta, ministro italiano de Asuntos Exteriores, comunicó al embajador en Madrid que el gobierno de Roma se alegraba por la resolución y, sobre todo, por el hecho que la motivaba.

La proclama del presidente Grover Cleveland mejoraba la situación. Evitaba una reacción antiespañola en medio de la campaña presidencial. ${ }^{78}$

En plena crisis europea, poco podría esperarse de las potencias. ${ }^{79}$ No valían los argumentos jurídicos, ni siquiera las razones de conveniencia. El

74 Este aspecto, que no había podido incluirse en el memorándum, fue objeto de la comunicación particular del ministro. AMAE H 2416, Real orden circular al conde de Casa Valencia, embajador en Londres, al marqués de Hoyos, embajador en Viena, a Felipe Méndez Vigo, embajador en Berlín, al conde de Benomar, embajador en Roma, y al conde de Villagonzalo, embajador en San Petersburgo, 28 de julio.

75 AMAE H 2416, telegrama cifrado Tetuán-Embajadores, 8 de agosto. Al responder a la notificación del ministro de Estado, Cánovas pidió orden en la acción del ministerio. "Puede declararse que el documento queda en poder de nuestros representantes a título de mera instrucción para poder explicar y noticiar la situación de Cuba y la actitud del gobierno, cuando sea indispensable, pero sin leerlo y menos dar copia a nadie".

76 El ministro de Estado quedó completamente satisfecho de la explicación que le dió H. Taylor. Informó el 11 de agosto a Cánovas y al ministro de España en Washington. Ese mismo día, en el ya citado comentario de The Standard apareció la noticia de la entrevista y de su buen resultado. AMAE H 2416, 593 Conde de Casa Valencia-Tetuán, 11 de agosto.

77 AMAE H 2416, telegrama cifrado Tetuán-Dupuy de Lome, 20 de agosto.

78 31283/143 Visconti-Renzis, 20 de agosto de 1896, Documenti Diplomatici Italiani, Roma, 1953, págs. $122-123$.

79 “... mi impresión es... que la Europa, preocupada hoy por la cuestión de Oriente”, y pendiente de los resultados del viaje de Nicolás II, permanecerá inactiva, salvo que hubiera un conflicto con Estados Unidos. La proclama del presidente Cleveland lo alejaba. Así las cosas, era difícil que Europa "entre ahora, ni aun confidencialmente, en acuerdos y conciertos para eventualidades que considera lejanas". Con esa perspectiva, Emilio Visconti Venosta había juzgado un acierto paralizar la entrega del memorándum. AMAE H 2416, 176 Benomar-Tetuán, 16 de agosto. Compartía este criterio el príncipe Lobanoff. 53 Villagonzalo-Tetuán, 17 de agosto. 
marqués de Hoyos expuso a Goluchoswki el valor estratégico que tenía para Europa que Cuba siguiera bajo la soberanía de España. La apertura del Canal de Panamá la situaba en una área vital para el comercio internacional y para la navegación. ${ }^{80}$

En el Congreso de los Diputados, al contestar al diputado Tesifonte Gallego, Cánovas reveló que hubo una conversación privada y confidencial, bastante extensa, entre el ministro de Estado y el ministro plenipotenciario de Estados Unidos. En ella se constató la amistad entre los dos gobiernos. Cánovas desmintió la existencia del memorándum. Se pensó en un escrito, resumiendo y dejando constancia de las gestiones realizadas y consignando lo que deberían saber los representantes de España ante otros Estados. Las dificultades con Washington surgían de las autoridades locales, cuyas competencias impedían la intervención de la administración federal. ${ }^{81}$

La solución debería brotar de la reflexión y fijar luego los intereses a tutelar y los beneficios a obtener. No podría reaccionarse sin tasar ni medir unos y otros. Estaban en juego el valor de una nación y la fortaleza de su gobierno para enfrentarse a los problemas. Tuvo que recordar Cánovas a uno de los jefes del carlismo la intervención de los norteamericanos en el reciente litigio entre Venezuela y el Reino Unido. ${ }^{82}$

El 9 de septiembre hablaron en París el duque de Mandas y Gabriel Hanotaux. Éste, al igual que su colega italiano, juzgó acertada la decisión de España, especialmente en un año en que había elecciones en Estados

80 El canciller austríaco se abstuvo de opinar y de prometer apoyo. AMAE H 2416, reservado 67, Hoyos-Tetuán, 17 de agosto.

81 Debate entre Cánovas y Tesifonte Gallego, Diario de las Sesiones de Cortes. Congreso de los Diputados 79 (17 de agosto de 1896), págs. 2385-2389. Gallego mencionaba la posible contradicción entre lo que se había dicho sobre el contenido del documento y las unánimes declaraciones de los ministros ante las Cortes afirmando que la postura norteamericana era correcta y amistosa. El diputado fue autor de La insurrección de Cuba. Crónica de la campaña. I. La preparación de la guerra, Madrid, 1897. Es una dura crítica a la administración española, que consintió con su tolerancia la organización de los revolucionarios.

82 “... según el derecho internacional estricto, Inglaterra podría entenderse con Venezuela libremente, para hacerla o para no hacerla justicia... en una cuestión que en nada concernía a los Estados Unidos. ¿Pues qué ha sucedido? Que los Estados Unidos se han interpuesto; que han declarado que tenían que examinar la cuestión de los límites ellos de por sí para juzgar si tenía o no razón Inglaterra...

Seguramente Inglaterra no es una nación que no sea viril. El día que la desgracia quiera que la Europa baje a los campos de batalla y que una guerra se esparza por los mares del globo, ese día se verá si Inglaterra es una de las Naciones que más conserva la virilidad y la energía militar, como todas las energías”. Debate Cánovas-Juan Vázquez de Mella, Diario de las sesiones de Cortes... 79 (17 de agosto de 1896), pág. 2393. 
Unidos. En la conversación, Hanotaux avisó que la posición internacional de Francia no le permitía hacer lo que deseaba en favor de España. ${ }^{83}$

\section{Cuba: guerra o negociación}

¿Haría el gobierno de Cánovas una apuesta final para acabar la guerra? Así lo creía el representante del partido revolucionario cubano en París. ${ }^{84}$ Una de las alternativas era un armisticio: saldrían las tropas de Cuba, conservando España una soberanía aparente. Cuba pagaría un tributo y se mantendría la bandera española. Sería una situación similar a la de Egipto en el Imperio Otomano. Si se abriera paso esa propuesta, Sagasta asumiría el poder y negociaría con el gobierno de los insurgentes. ${ }^{85}$ De esta forma se salvaba el honor y se abría un procedimiento aceptable para los españoles. ${ }^{86}$

$\mathrm{Al}$ acabar la campaña anterior, el balance no era muy satisfactorio, según el cónsul de Italia en La Habana. Los generales senadores, que habían tenido mando en Cuba, no ocultaron que la situación militar en la isla tenía un horizonte poco tranquilizador ${ }^{87}$ Lo sabían también los revolucionarios cubanos, atentos a los gestos y actos que manifestasen el cansancio del gobierno de Madrid. La entrevista de Sagasta con la Reina Regente revelaba una situación "bastante crítica". ${ }^{88}$

83 Hanotaux se quejó de haber sido mantenido al margen, aunque era explicable debido a la ausencia del embajador francés en Madrid. H. de Reversaux estaba enfermo. AMAE H 2416, 280 Mandas-Tetuán, 10 de septiembre.

84 "Cánovas se propone hacer lo imposible... durante la estación seca y, si no obtiene mejor resultado que hasta ahora, se retirará del poder y cederá el puesto en marzo a Pidal, cuya misión será "firmar la evacuación de Cuba"... Este informe me llega por uno de los nuestros de la embajada española en París... Ninguno de los ministros, ni él mismo, cree hoy que España pueda dominar la revolución, pero hacen un esfuerzo desesperado". Ramón Emeterio Betances-Tomás Estrada, 29 de septiembre, Correspondencia Diplomática de la Delegación Cubana en Nueva York durante la guerra de la independencia de 1895 a 1898, III, La Habana, 1945, págs. 71-72.

85 "Si eso — que me parece a mí serio y digno de discutirse — no conviene sírvase ponerme cuanto antes un cablegrama: "imposible"“. Betances-Estrada, 2 de octubre, ibídem, págs. 74-75.

86 "Yo entiendo que al cabo de uno, dos o tres años, España se conformaría con una denunciación del Tratado, retirando su bandera y cambiando el tributo por una indemnización. En resumidas cuentas, cuestión de palabras. Piénselo". Betamces-Estrada, 9 de octubre, ibídem, pág. 78.

87 ASD SP P 71 1896, 233/56 Marefoschi-Caetani, La Habana julio, y 463/153 RenzisCaetani, Madrid, 8 de julio.

88 "Confidencial: la llegada de Sagasta al poder — de acuerdo probablemente con Martínez Campos - había de coincidir con las negociaciones que habían venido aquí a entablar y el comisionado era un antiguo embajador en Roma, en Constantinopla y Berlín, el Sr. conde de Rascón”. BetancesEstrada, 4 de diciembre, Correspondencia diplomática... III, págs. 83-84. 
En las elecciones norteamericanas triunfó el candidato republicano. Era el menor de los males. Durante su campaña W. McKinley guardó silencio sobre Cuba, a pesar de que el reconocimiento de los rebeldes estaba en el programa de su partido. Pese a eso, se pidió al general Valeriano Weyler rapidez y energía. Urgía intensificar las operaciones militares y obtener un triunfo decisivo antes del 4 de marzo. Ese pudo ser el objetivo de la campaña en Pinar de Río para cercar a Maceo. Había en Cuba 200.000 soldados, los insurgentes eran unos $40.000{ }^{89}$

No estaba mal informado Betances, delegado cubano en París. En la audiencia con la Reina, el jefe del partido fusionista se mostró dispuesto a negociar con los independentistas la autonomía. Podría ser un precio aceptable, pues existía una opinión casi unánime, "en dehors de la Catalogne et de la Biscaye", en favor de la paz. Esta opción, sostenida en la prensa de la oposición liberal, en la silvelista y en los consejos de Sagasta a la Reina, se reforzaba con el cansancio que sentían los españoles. Sólo eran reticentes la "camarilla" y Francisco Romero Robledo. ${ }^{90}$ Cánovas era más flexible. ${ }^{91}$ En unas declaraciones a un periodista norteamericano anunció reformas en Puerto Rico, que se introducirían luego en Cuba. ${ }^{92}$

El senador Cameron presentó una resolución reconociendo la independencia de Cuba y pidiendo los buenos oficios de Estados Unidos ante España para que cesara la guerra. Era un paso peligroso. El gobierno de Cánovas advirtió al secretario de Estado que, si aprobaban la resolución las dos Cámaras y la sancionaba el presidente, España la consideraría una declaración de guerra.

89 ASD SP P 71 1896, 664/214 Renzis-Visconti, 12 de octubre y 718/237, Malaspina-Visconti, 6 de noviembre de 1896. La gestión de Weyler y su justificación se recoge en Mi mando en Cuba, 10 de febrero de 1896 a 31 de octubre de 1897). Historia militar y política de la última guerra separatista durante dicho mando, 5 tomos, Madrid, 1910-1911. El texto reproduce muchos documentos y comentarios de prensa.

90 “Toute la question est là". AAE CP Espagne 929, 198 Reverseaux-Hanotaux, 10 de diciembre, págs. 407-408. El embajador comentaba la situación creada tras el discurso de Groover Cleveland y la muerte de Antonio Maceo. La coincidencias de Silvela y Moret, 199, 11 de diciembre, ibídem, págs. 410-411. Sobre la gestión de los embajadores de las potencias en Washington, 206, 26 de diciembre, ibídem, págs. 433-434. Betances agrandó el impacto que tuvo la muerte de Maceo, un "crimen, imaginado por Cánovas y ejecutado por Weyler y Cirujeda". El análisis de la prensa de París sobre el efecto que este hecho tendría en la marcha de la guerra, Betances-Estrada, 18 y 25 de diciembre, 12 de enero de 1897, Correspondencia diplomática... III, págs. 85-87 y 91.

91 El estudio más completo es el de Roldán Montaud, Inés: La Restauración en Cuba. El fracaso de un proceso reformista, Madrid, 2000, especialmente págs. 602-625.

92 Comentario sobre esta orientación de Cánovas, AAE CP Espagne 929, 204 y 206, Reverseaux-Hanotaux, 19 y 26 de diciembre. Se envió traducción de las declaraciones de Cánovas sobre Puerto Rico y Cuba, págs. 422, 433-434 y 425-426. 
Ese acto contradecía la abstención expectante del presidente Grover Cleveland. R. Olney recordó al Congreso que reconocer a un Estado extranjero era competencia exclusiva del poder ejecutivo. Pese a eso, se aprobó la resolución. Además de crear un problema con España, abrió un conflicto entre el legislativo y el presidente. Era una prueba de fuerza, pues el Congreso no podría tomar una decisión final antes del 4 de marzo, fecha de inicio de la nueva administración..$^{93}$

Como informaba el embajador Reverseaux a su gobierno, había en España una corriente partidaria de la paz, aunque su precio fuera un tratado de comercio favorable a Estados Unidos. Esa tesis la defendían Castelar, Valera, Moret y Silvela. Cánovas, en cambio, decía que nada podía hacerse si antes no se conseguía una victoria, "pacificando" una parte de la Isla o mediante una derrota importante infringida a los independentistas. En un comunicado oficioso redactado por él mismo y aparecido en La Época, decía que si la opinión deseaba en esos momentos la paz, el gobierno consideraría fracasado su programa. ${ }^{94}$

Castelar declaró a dos periodistas extranjeros que los avances políticos en Cuba en los últimos años dejaban sin razón a los rebeldes. Estaba de acuerdo con Cánovas: ser implacables en la guerra, liberales y generosos tras la victoria. Algunos norteamericanos hacían un alarde de cinismo al negar a España lo que ellos mismos consideraban su derecho: hacer la guerra a los que buscaban romper su unidad nacional. Cleveland había salvado la situación creada por el Senado. Esperaba que McKinley siguiera la misma conducta. El principio de no intervención es fundamental en las democracias. Fue la base de la doctrina Monroe. En las palabras del jefe republicano, otro gesto coincidente con los demás políticos españoles: escuchamos las amenazas con el estoico desprecio de quienes creen en la justicia de su causa..$^{95}$

93 La Nota de Olney en francés y "The Report on Cuba" del Senado, resumido en italiano, ASD SP P 71 1896-1897, 807/279 Costa-Visconti, Washington 22 de diciembre de 1896.

94 s.n. Renzis-Visconti, 18 de enero de 1897. En la situación militar, la muerte de Antonio Maceo fue el único éxito importante desde que se inició la sublevación. 812/267 Renzis-Visconti, 10 de diciembre y 427/87 y 437/91 Marefoschi-Visconti, 11 y 25 de diciembre de 1896, ibídem, 1896 y 1896-1897. El diputado Imbriani hizo un elogio de Maceo el día 11. Dada su significación política y considerando la reacción de la Cámara, el acto carecía de importancia. El gobierno italiano lo desaprobó y Renzis dio explicaciones al duque de Tetuán. 862/287, 23 de diciembre. El ministro de Estado ordenó al embajador en Roma que agradeciera las manifestaciones del marqués di Rudinì, presidente del consejo italiano. Copia del telegrama, 23 de diciembre, ibídem, 1896.

95 Aunque el embajador de Italia en Madrid atribuía estas palabras a un "filósofo" y no a un político, era innegable que expresaban una opinión, que prevalecería durante la crisis. 863/288 RenzisVisconti, 24 de diciembre de 1896, ibídem, 1896. 
La iniciativa de Senado norteamericano pesó más que la euforia por la muerte de Maceo. En esas circunstancias, la importancia de la guerra en Filipinas crecía hasta el punto de que los cónsules de Francia, Inglaterra y Alemania pidieron naves de guerra para proteger a sus conciudadanos. Aunque la situación se agravara en aquellas islas, el mayor peligro estaba en las Antillas. La hostilidad norteamericana podría empujar al presidente McKinley a "arrancar" una página del derecho internacional y decidir una intervención en Cuba.

Cánovas ni siquiera aceptaba la mediación amistosa. Las reformas estaban recogidas en el programa del gobierno conservador. Se aplazaba su puesta en practica no por amor propio, sino por ser materialmente imposible hacerlo en un país en armas. Taylor creía que no era así. Juzgaba a Cánovas un intransigente. El aplazamiento impedía a los cubanos creer en las promesas dadas.

El problema de fondo era que, para los españoles las reformas eran sólo una rectificación de los abusos. Y Estados Unidos deseaba otra cosa: un régimen aduanero libre y un tratado de comercio que permitiera una mayor exportación de sus productos que les compensara por la compra de materias primas en la isla. Acceder a esa demanda arruinaría a Cataluña y Andalucía y reduciría los ingresos aduaneros, garantía de los Bonos de Cuba, cuyos titulares eran europeos.

El reconocimiento de la independencia se prorrogaría, si Cleveland actuaba sin doblez. Su mensaje al Congreso causó buena impresión. Cánovas y sus ministros estabas satisfechos. El Imparcial dijo que Cleveland aceptaba que la guerra en Cuba era un asunto interno. El que se mencionara el problema parecía al Heraldo una humillación, que rebajaba a España a la misma consideración que se tenía con Bulgaria y Serbia. La Época, recordando que el Mensaje no es el programa de la administración, sino un repaso a los acontecimientos del año, subrayó la nula simpatía con que trataba a los rebeldes y a los que cooperaban con ellos en Estados Unidos. En nada ofendía los derechos soberanos de España. Era la tesis sostenida también en la Correspondencia de España. Medidas políticas y una acción militar para alcanzar el único objetivo que urgía: la paz. Creía El Globo que la aplicación de unas reformas, unánimemente votadas en las Cortes, pondría al lado de España a las potencias europeas. Se recuperaría así el tiempo perdido, después de haber cometido el error de rechazar los buenos oficios de Olney. ${ }^{96}$

96 El ministerio conservador, según reveló el duque de Tetuán, ganaría la guerra mediante una enérgica acción militar. Luego, todo lo demás. 818/268 Malaspina-Visconti, 13 de diciembre, ibídem, 1896. Las buenas noticias sobre las operaciones de Weyler, que proporcionaban solidez a esa decisión, 773/257, 25 de noviembre. 
Si se pacificaba Cuba, quedaría sin argumento Estados Unidos. Cabría, tras la muerte de Maceo, negociar con Gómez y Calixto García que, en otras ocasiones, no rechazaron la entrega de dinero. A favor de esa vía, la experiencia de la insurrección anterior y la "victoria" de Cánovas sobre el carlismo, según comentaban en Madrid algunos diplomáticos.

Mientras Taylor era más explícito que su presidente a la hora de hablar de una intervención norteamericana, las potencias europeas se desinteresaban. Aconsejaban, pero no prometían ni adquirían la obligación de ayudar a España. Drummond Wolff le dijo a Renzis que el pequeño burgués inglés no se calienta la cabeza por la doctrina Monroe. No se moverían para impedir su aplicación ${ }^{97}$.

\section{Comunidad de intereses en el Mediterráneo}

Cerrada en un círculo de incertidumbres la política exterior, las potencias europeas se acechaban mutuamente. Vigilaban los pasos de las demás. Los frecuentes contactos entre J. M. Radowitz, embajador alemán en Madrid, y Cánovas levantaron sospechas. Se pensó que Alemania estaba en la mejor disposición hacia España. ${ }^{98}$ No era verdad. ${ }^{99}$ Había crecido su prestigio los días anteriores a la redacción del memorándum del duque de Tetuán. Se benefició de la mala gestión de Drummond Wolff, cuyas intrigas habían fracasado. Contra Francia estaban el poco éxito del empréstito cubano y la tolerancia de su gobierno con Ramón E. Betances. ${ }^{100}$

Salisbury aludió al monroísmo y su impacto en la conducta de Estados Unidos en el conflicto de Inglaterra con Venezuela. ${ }^{101} \mathrm{Y}$ defendió el derecho de una potencia marítima a intervenir en todo lo que afecta a sus costas. Según el embajador francés en Londres, apuntaba a Marruecos, un país

97 R. 843/281 Renzis-Visconti, 20 de diciembre de 1896, ibídem, 1896.

98 La prensa republicana hizo una campaña contra una posible alianza con Alemania. AAE CP Espagne 929, 166 Pasteur-Hanotaux, 30 de octubre, págs 293-294.

99 A la hora de la verdad, Cánovas se limitó a otorgar a Alemania las ventajas concedidas a Suiza, es decir, las mismas que tenía el Tratado Comercial vigente con Francia. 172, 4 de noviembre, ibídem, pág. 314.

100 Cánovas “m’a parlé, en termes asez amers du peu du concours financier qu'il avait trouvé en France, pour les aider à faire face aux difficultés de l'heure présente". 176 Reverseux-Hanotaux, 14 de diciembre, ibídem, págs. 331-332.

101 Ickringill, Steve J.S. y Hilton, Sylvia L.: "Cleveland and the Anglo-Venezuelan dispute in 1895: A prelude to Mckinley's intervention in the Spanish-Cuban War", en Antes del "desastre". Orígenes y antecedentes de la crisis de 98, Madrid, 1996, págs. 337-358 
rico, de buen clima, pero políticamente mal gobernado y entregado a la barbarie. Ese estado de cosas creaba deberes a las potencias. ${ }^{102}$

Durante su visita a París, Muravieff aseguró la continuidad entre la política de Alejandro III y la de Nicolás II. Nadie había cometido el error de creer que hubiera variado. ${ }^{103}$ Se habló de las relaciones entre Francia y Alemania. Habían mejorado, pero no se había producido una aproximación. En París deseaban recuperar Alsacia y Lorena por medios pacíficos. Para lograrlo, no existía un compromiso con los rusos. ${ }^{104}$ Los intereses de estos eran antagónicos con los alemanes en Oriente. Muravieff, pese a las declaraciones que le hicieron Visconti Venosta, el marqués di Rudiní y el rey Humberto, creyó que apostaban por la alianza con Alemania, tal como lo hizo antes Crispi. ${ }^{105}$

Marruecos era un problema ligado a la libertad de navegación y al control sobre los Estrechos. La cuestión debería plantearse de forma simultánea para todos ellos. Muravieff prometió estudiar esa propuesta. ${ }^{106}$

En el otro campo, Goluchowski, el canciller austríaco, tras su viaje a Berlín, hizo este balance. En Turquía continuaría la pasividad de Alemania. Hohenlohe estaba más interesado en los asuntos internos. Guillermo II dirigía la política exterior. ${ }^{107}$ Para el canciller austríaco bastaba con que los tres aliados examinaran la propuesta que los representantes de las potencias en Constantinopla presentaran.

102 'L'Espagne, la France, et l'Italie étaient avec l'Angleterre, les puissances qui surveillent cet Empire en se surveillant réciproquement, et c'était certainement le devoir de l'Angleterre de veiller à ce qu'il n'y fût pas porté atteinte à ses intérêts". 19 Barón de Courcel-Hanotaux, Londres 18 de enero de 1897, Documents Diplomatiques Français, v. XIII, Paris, 1953, págs. 116-120.

103 Las declaraciones del ministro de Asuntos Exteriores ruso tras su estancia en París y la impresión favorable causada por ellas, 6 Montebello-Hanotaux, 15 de enero de 1897, y 41 HanotauxMontebello, 30 de enero, ibídem, págs. 112-113 y 148-149. Sobre Alejandro III, Bensidoun, S.: Alexandre III (1881-1894), Paris, 1990; y "Un Tsar méconnu: Alexandre III (1881-1894)", Revue Historique, 584, 1993, págs. 429-441.

104 Sobre esta falta de simetría en el pacto, Iiams, Thomas: Dreyfus, diplomatists and the Dual Alliance, Gabriel Hanotaux at the Quai d'Orsay, 1894-1898, Genève-Paris, 1961. Rusia, frente a Alemania y Austria, se beneficiaba de la ayuda de Francia y a nada se obligaba con Francia respecto a Alemania.

105 “... je n'ai jamais cessé de considérer cette adhésion (à la Triple Alliance) comme motivée surtout par des préoccupations dynastiques”. Estas palabras del cardenal Rampolla, secretario de Estado, a Navenne, el encargado de negocios francés ante la Santa Sede, reforzaban la comunidad de intereses del Vaticano con la III República. A las dos partes convenía que no se estabilizara la dinastía que hizo la unidad de Italia. 117 Navenne-Méline, 30 de agosto de 1897, Documents Diplomatiques Français, v. XIII, pág. 521.

106 "Les inmtérêts des deux pays ne sont hereusement inconciliables sur aucun point" Era esta una sólida base de entendimiento. Muy confidencial y sin número Hanotaux-Montebello, 31 de enero de 1897, ibídem, págs. 150-150. Entrevista del embajador con el ministro de Exteriores ruso, R. 12 Montebello-Hanotaux, 8 de febrero, ibídem, págs. 169-172.

107 Véase la Correspondencia secreta entre Bûlow y Guillermo II, Madrid, 1932. 
En las relaciones de Alemania con el Reino Unido, trató Goluchowski de reducir y disipar la desconfianza mutua. Necesitaba y pedía la cooperación italiana para aprovechar todas las oportunidades de mejorarlas. Costantino Nigra le dijo que Visconti estaba convencido de la necesidad de "vedere con noi l'Inghilterra per gli affari del Mediterraneo". ${ }^{108}$

Alemania se hacía la ilusión de que la alianza franco-rusa había perdido intensidad. Pero el nombramiento de Muravieff suponía la continuidad de la política rusa, como demostró la acogida de ese nombramiento en Francia. ${ }^{109}$ Muravieff, durante su estancia en Alemania, se manifestó contrario a cualquier aventura. ${ }^{110}$ Deseaba mantener la armonía con las potencia y proceder en unión con Austria-Hungría. Dejó traslucir desconfianza hacia el Reino Unido y una menor sintonía con Hanotaux. ${ }^{111}$

Desde el otoño de 1896 había estado atento el embajador italiano en París a los preparativos militares de Francia en Túnez. Todos los ministros de Exteriores le habían asegurado que Francia no tenía el proyecto de apoderarse de Tripolitania. Las complicaciones en Oriente plantaban a la opinión francesa la posibilidad de un desembarco italiano en aquella zona. Hanotaux estaba preocupado por las repercusiones que la crisis pudiera tener en los países ribereños del Mediterráneo. Entre Italia y Francia estaba la presión de sus ciudadanos, que mantenían aún vivos el resentimiento y el recelo. ${ }^{112}$

108 Sobre Nigra, Chabod, Federico: Storia della politica estera italiana dal 1870 al 1896. Volume primo: Le premesse, Baris, 1951, págs. 600-618. La vinculación de Nigra con la masonería, Mola, Aldo A.: Storia della Massoneria Italiana. Dalle origini ai nostri giorni, Milano, 1994, XVIII y $65-66,222,404$ y 732 .

109 Carta particular Nigra-Visconti, 23 de enero de 1897, Documenti Diplomatici Italiani... Roma, 1953, págs. 249-250.

110 En enero de 1897 se desechó la posibilidad de una alianza entre Rusia, Francia y Alemania para frenar a los ingleses en Oriente. Hanotaux esperaba que surgieran rivalidades entre Alemania y el Reino Unido. Convenía esperar. Se abría un horizonte de paz. Nicolás II convocó en 1898 a una conferencia de desarme. Francia y Rusia no rompieron Inglaterra. La primera se aproximó a Italia. Los apuntes de Hanotaux sobre la visita a Rusia en agosto de 1897, "Notes sur le voyage à Petersbourg. Entretiens avec l'Empereur et avec le comte Mouravieff", editadas por Dethan, Georges: "Les papiers de Gabriel Hanotaux et la proclamation de l'entente franco-russe (1895-1897)", Revue d'Histoire Diplomatique, 80, 1966, págs. 205-213.

111 T. 329 Lanza-Visconti, 2 de febrero, Documenti Diplomatici Italiani..., Roma, 1953 pág. 252. Sobre las relaciones entre Viena y Roma, Bridge, F. R.: From Sadowa to Sarajevo. The Foreing Policy of Austrian-Hungery, 1866-1914, London-Boston, 1972, Supo Austria mantenerse en el grupo de las grandes potencias sin poseer un gran poder militar, cuya creación fue dificultada por el Reino de Hungría, que no votó los créditos. Para las relaciones con sus aliados, Pribram, A,: Les traités politiques secrets de l'Autriche-Hongrie 1879-11914, traducción del alemán, Paris, 1923.

112 Como ejemplo de influencia imagen, opinión, estereotipos y prejuicios, Askew, W. C.: "The Austrian-Italian Antagonism, 1896-1914”, Power, Public Opinion and Diplomacy, Durham, 1959, 172-221. Para un planteamiento teórico, Duroselle, Jean-Baptiste: "Opinion, attitude, mentalité, mythe, idéologie: essai de clarification”, Relations Internationales, 2, 1974, págs. 2-23. 
¿Se había dejado influir el embajador por el razonamiento de sus interlocutores franceses? Tornielli dijo que uno de los peligros mayores para la paz en Europa radicaba en la existencia de pactos secretos, cuya importancia unas veces se exageraba y otras se negaba. Urgía arreglar los contenciosos, no dejando que pasara el tiempo por ellos ni guardando silencio, fingiendo ignorar su existencia. ${ }^{113}$

Visconti creía que en el norte de África, además del "mutuo desinterés", había otras dos soluciones. Una, indicar a Francia que la ocupación de las costas de Tripolitania constituían un casus foederis para la Triple Alianza. Otra, un intercambio de explicaciones que eliminara las dudas recíprocas. Esta última tenía dos objeciones: se adelantaba demasiado a los acontecimientos y su eficacia no era segura. ${ }^{114} \mathrm{La}$ mejor salida, notificar a Berlín la eventual acción francesa. Italia tenía acuerdos con Alemania sobre el mantenimiento del statu quo en el Mediterráneo, que legitimaban apelar a un casus foederis. ${ }^{115}$

El 16 de marzo el ministro de Exteriores envió copia del despacho de Tornielli al embajador en Berlín. Secundaba así la propuesta de Nigra. Adelantaba una posible declaración de los gobiernos de París y Roma. Quería saber la posición del barón Marshall. ${ }^{116}$ Éste no pensaba que Francia tuviera intenciones expansivas en Tripolitania. Por otra parte, el gobierno francés no se comprometería por escrito. Por esta razón, fracasaría la iniciativa. ${ }^{17}$ En Viena, sin embargo, estaban seguros de que Francia no se apoderaría de Tripolitania. ${ }^{118}$ Para entonces en Roma conocían que Austria no

113 Riservatissimo 773/221 Tornielli-Visconti, 8 de marzo de 1897, Documenti Diplomatici Italiani..., Roma, 1953, págs. 279-280.

114 Pedía la opinión del embajador en Viena. Telegrama personal, sin número Visconti-Nigra, 8 de marzo, ibídem, págs. 280-281.

115 "Credo che tutte le potenze desiderano sinceramente evitare le occupazioni parziali, prevedendo le conseguenze che possono derivarne". Austria no deseaba ocupar ningún territorio en los Balcanes. Goluchowski temía que, previendo ese acto, se anticipara Francia en Tripolitania. Telegrama privado Nigra-Visconti, 10 de marzo y carta particular, 11 de marzo, confidencial sin número, 12 de marzo, ibídem, págs. 283-287.

116 Se excluía un protocolo, porque ese acto podría oscurecer la clara y neta posición de Italia dentro de la Tríplice Alianza. "Basterebbe invece una semplice spiegazione sotto forma di reciproca dicchiarazione tra l'Italia e la Francia dei rispettivi intendimenti". El texto podría ser: "Lo scopo delle Potenze nella presente crisi orientale essendo la conservazione dello statu quo territoriale dell'Impero Ottomano, il governo italiano e il governo francese si dànno la mutua assicurazione, per quanto reciprocamente li concerne, di volere specialmente rispettare questo statu quo sulla costa mediterranea dell'Africa". Muy confidencial y sin número, Visconti-Lanza, 16 de marzo, ibídem, págs. 290-291.

117 No quiso comprometerse si quiera a dar un consejo, carta particular Lanza-Visconti, 25 de marzo, ibídem, págs. 302-303.

118 Carta particular Nigra-Visconti, 25 de marzo, ibídem, págs. 302-303. 
tenía intención de realizar ningún movimiento que sirviera de pretexto a Francia. Todo quedaba en suspenso. ${ }^{119}$ Si Francia nada hacía, se limitaría Italia a presentar ante Alemania la existencia de un casus foederis. ${ }^{120}$

No confirmaba esa impresión el despacho que envió a París el cónsul italiano en Tripoli. ${ }^{121}$ Confirmada la alarma por el cónsul de Italia en Túnez y el vice-cónsul en Susa, había que pedir explicaciones a Hanotaux y reiterarle que Italia no consentiría que se modificara la situación en Tripolitania. ${ }^{122}$ Estando conformes los dos gobiernos y siendo falsas las noticias sobre los movimientos de tropas francesas, Hanotaux se adelantó la propuesta de Visconti sobre una explicación bilateral. ${ }^{123} \mathrm{El}$ procedimiento debería ser muy sencillo. En un despacho de Tornielli, Hanotaux consignaría su conformidad con lo que el embajador afirmaba. Y un resumen de ese texto podría enviarlo el ministro francés a Albert Billot, embajador en Roma. ${ }^{124}$

Los recelos de Italia hacia Francia en el norte de África se basaban en el valor de aquel territorio para una nación asentada ya en Argelia y Túnez. Se establecía un contacto entre las posesiones francesas y las mal gobernadas regiones bajo control turco.

Italia repetir lo que sucedió Túnez en 1881. Por eso se condujo el embajador Tornielli con prudencia, exigiendo siempre de manera amistosa las explicaciones que su gobierno necesitaba o podría precisar. Hanotaux iba en esa misma dirección. Quería librar a Francia de un conflicto con Italia.

Tripolitania estaba cubierta por la misma garantía que protegía al Imperio Otomano. Así las cosas, ya no urgía como meses antes un entendimiento con Francia sobre el mutuo desinterés de ambas en aquel territorio. Sin embargo, no responder afirmativamente a la oferta de Hanotaux podría dejar entrever que Italia no quería asumir ese compromiso.

La forma era importante. Un acuerdo verbal dejaba en peor situación a Francia, que entregaba dos testimonios frente a una mera confirmación

119 "Ciò essendo, ritengo che possiamo in questo momento astenersi dal fare a Parigi una apertura qualsiasi”. Telegrama sin número Visconti-Lanza, 26 de marzo, ibídem, pág. 303.

120 Hanotaux aseguró a Tornielli que nada haría Francia, reservado 1141/315 Tornielli-Visconti, 8 de abril, ibídem, pág. 307.

121 Reservado 1141/315 Tornieli-Visconti, 8 de abril, ibídem, pág. 307.

122 Telegrama 1284 Visconti-Tornielli, 4 de mayo de 1897. Era la misma política que respecto a los Balcanes habían acordado Francisco José I y Nicolás II durante sus entrevistas en San Petersburgo. Apunte de Visconti Venosta, 9 de mayo, ibídem, serie terza volume secondo, Roma, 1958, págs. 3 y 12.

123 Telegrama 1965 Tornielli-Visconti, 12 de mayo, y R. 1760/467, 14 de mayo, ibídem, págs. 18 y $23-24$.

124 Confidencial por correo sin número, Visconti-Tornielli, 17 de mayo, ibídem, págs. 29-30. 
del embajador de Italia de que la comunicación hecha a Albert Billot era correcta. ${ }^{125}$

\section{La difícil relación entre Francia e Italia}

La misión marroquí a París en la primavera de 1897 tenía estos objetivos: 1. vindicar los derechos del Sultán sobre Tuat, Guerara y Tidikelt; 2. reclamar la retirada de los franceses de algunos puntos donde habían construido fortificaciones, para asegurarse la posesión de las fuentes, no lejos del Figuit. Esas tierras eran de Marruecos; 3. discutir la posesión de Geliel Amur, cerca del Figuit, de gran valor estratégico; 4. la salida de la misión militar francesa en la corte de Marruecos donde estaba desde hacía 18 años; 5. el levantamiento de la orden de destierro contra uno de los sheriffs de Uasan, acusado de intrigar contra miembros de su familia protegidos por Francia; 6. la reducción de los derechos feudales de éstos y 7. apartar definitivamente de Fez al vicecónsul francés.

Esta lista no presagiaba un buen resultado. Los franceses no aceptarían discutir sobre el Tuat. Lo habían declarado así en ocasiones anteriores. Después de haber recuperado las fuentes del Figuit, no las dejarían. ${ }^{126}$

El gobierno francés quiso subrayar la importancia de la misión. Los embajadores de España y de Alemania le pidieron datos. A cambio de algunas concesiones en la frontera, quería conseguir Marruecos que se le permitiese cobrar tasas aduaneras, punto que Inquietaba al embajador alemán este punto. El de España temía que se produjera un acercamiento de las tropas francesas a los presidios españoles en la costa. ${ }^{127}$

Volviendo a la declaración franco-italiana, Visconti Venosta afirmó: "notre intention est que le statu quo soit maintenu en Tripolitaine; c'est-àdire dans la région comprise entre l'Egypte et les frontières de Tunisie et Algerie", pues pertenecía al Imperio Otomano, cuya integridad territorial estaba garantizada por las potencias europeas, que la consideraban la base principal para el mantenimiento de la paz. ${ }^{128}$

125 Reservado 1836/488 Tornielli-Visconti, 24 de mayo, ibídem, págs. 43-46.

126 ASD DDS XL/11, comunicación confidencial y secreta de Gianatelli Gentile, 30 de abril de 1897 en 211/48 Malmusi-Visconti Venosta, 9 de mayo, documento 2035, págs. 3-4.

127 Reservado 2176/582 Tornielli-Visconti, 21 de junio de 1897, Documenti Diplomatici Italalia... Roma, 1958, pág. 69.

128 Visconti recogía en este despacho las conversaciones del embajador italiano con el ministro de Asuntos Exteriores francés. Si le parecía adecuado su contenido, podría dar curso a la declaración mutua. 21366/536 y 21367/537 Visconti-Tornielli, 5 de junio, ibídem, págs. 57-59. El despacho corregido con las sugerencias del embajador, 22976/578 Visconti-Tornielli, 16 de junio, ibídem, pág. 67. 
El 9 de junio hablaron Tornielli y Hanotaux, que recordó que, además de Tripolitania, los dos países tenían más intereses comunes. La normalización de las relaciones comerciales debían poner fin a las sospechas y desconfianzas. Las concesiones hechas por Francia sólo podrían justificarse políticamente poniendo el contrapeso de la reanudación de la amistad entre las dos naciones. ${ }^{129}$

Este comentario revelaba que el acuerdo comercial provocó largos debates dentro del consejo de ministros. Hanotaux se quejó del silencio del embajador ante algunos asuntos, como los relativos al Mar Rojo. Se sabía que Italia dejaría Cassala, pero no a quién. Se volvía a la etapa en que Francia y el Reino Unido competían por el dominio de Egipto. Si se pensaba ceder a Inglaterra las posesiones italianas en el Mar Rojo, habría que renunciar a las buenas relaciones con Francia. Y eso repercutiría negativamente en las finanzas italianas. ${ }^{130}$

La índole parlamentaria de la III República, que colocaba bajo el control de los diputados y senadores la política exterior en todas sus fases, explicaba la sorprendente salida de Hanotaux. ${ }^{131}$ No era lógico que, al tiempo que se quitaba una razón de recelo en Tripolitania, se dejara otra en el Mar Rojo. La opinión francesa asociaba el acuerdo comercial con la vuelta a unas buenas relaciones políticas. ${ }^{132}$

Cuando Guillermo II invitó al rey Humberto a la maniobras militares que tendrían lugar en Hamburgo, ${ }^{133}$ hubo que aclarar que la permanencia en la Triple Alianza no excluía relaciones normales y hasta amistosas con otras potencias. La situación de Italia con Francia era semejante a la de Alemania con Rusia. El gobierno de Roma reanudaba la amistad con Francia para favorecer la paz en Europa.

129 Los antecedentes, Izzo, Luigi "Vicende della politica commerciale italo-francese dal 1860 al 1892": L'economia italiana prima e dopo l'Unità. Atti del XXXIV Convegno di Storia del Risorgimento Italiano (Venezia 20-23 ottobre 1955), Roma, 1958 págs. 206-224.

130 Riservatissimo 2044/548 Tornielli-Visconti, 9 de junio, Documenti Diplomatici Italalia... Roma, 1958, págs. 59-63. Visconti se negó a admitir compromisos políticos ligados a una negociación que era económica. T.s.n. Visconti-Tornielli, 13 de junio, ibídem, pág. 65. El gobierno italiano necesitaba saber cómo se produciría la evacuación de Cassala. Reservados 27529/188 y 29498/200 ViscontiFerrero, 22 de julio y 5 de agosto, ibídem, págs. 95-96 y 114-115. Cassala pasó al control anglo-egipcio con el beneplácito de Italia. Telegrama 2706 Visconti-Ferrero y Visconti-Tugini, cónsul en El Cairo, 2 de noviembre de 1897, ibídem, pág. 196.

131 Una exposición más extensa, muy reservado 2185/584 Tornielli-Visconti, 22 de junio, ibídem, págs. 70-73. y telegrama 2529 Tornielli-Visconti, 27 de junio, ibídem, pág. 78.

132 Telegrama muy reservado sin número Tornielli-Visconti, 14 de junio. A la vista de la nueva situación y tras consultar con el marqués di Rudinì, Visconti ordenó al embajador que se abstuviera de cualquier iniciativa. Despacho sin número, Visconti-Tornielli, 17 de junio, ibídem, págs. 65-66 y 67-68.

133 Telegrama 2455 bis Lanza-Visconti, 19 de junio de 1897, ibídem, págs. 68-69. 
En política interna, los objetivos del gobierno di Rudinì eran el saneamiento financiero y del crédito y reavivar la economía. La hostilidad del capital francés y la ruptura comercial impedirían alcanzarlos. Así lo explicó el ministro de Exteriores al embajador Bülow antes de que marchara a Berlín.

Pasos en esa dirección fueron el acuerdo sobre Túnez, la visita del Príncipe Real a París, de camino hacia Londres, y las numerosas pruebas dadas hasta entonces para demostrar su voluntad de acercamiento a Francia.

Bajo el más estricto secreto, impuesto por el gobierno francés para sorprender a los proteccionistas, se comunicó al embajador en Berlín que se negociaba un tratado de comercio.

Las relaciones bilaterales con Francia eran un edificio frágil en ese momento. El viaje del rey a Alemania podría derribarlo. Si sucediera eso, caería la popularidad de la Triple Alianza, pues demostraría que dañaba a Italia.

No podría rechazarse la invitación del Emperador, pero se encomendaba a Lanza que atenuara el efecto. Para eso, se proyectaba que el Rey fuera Alemania con un séquito militar, pero sin acompañamiento político. ${ }^{134}$ El gobierno francés conocía las circunstancias políticas en que habría de llevarse adelante la negociación. No tendría que extrañarse de una visita prevista y de mera cortesía. ${ }^{135}$

Las consecucuencias previsibles, expuestas en su correspondencia por el embajador en París, afectaron al ministro de Asuntos Exteriores. Era inevitable que el Humberto I devolviera la visita a Guillermo II. Además Hanotaux no podría pedir a Italia que abandonara las líneas básicas de su política internacional y las seguridades que esta le proporcionaba a cambio de un tratado que no pasaba de mediocre. En cualquier caso, Francia sabía que las alianzas de Italia eran públicas y con compromisos precisos. No podría esperar de Italia actos hostiles ni sobresaltos. Por eso el mayor logro de Francia sería "colla pacificazone economica, colla solidarietà degli interessi creare un ambiente favorevole alla sua politica, la quale non può avere delle scandenze inmediate". ${ }^{136}$

134 Carta particular Visconti-Lanza, 30 de junio, ibídem, págs. 80-83. Se informó a París. El embajador creyó conveniente que los ministros no acompañaran al Rey. Telegrama sin número Tornielli-Visconti, 10 y 12 de agosto, ibídem, págs. 125 y 126.

135 Carta particular Visconti-Tornielli, 16 de julio. Telegrama reservado y sin número TornielliVisconti, 21 de julio, y carta particular, 25 de julio, ibídem, págs 90-11, 94 y 99-100.

136 Visconti era partidario de proseguir la negociación respondiendo a las demandas francesas. No había que romper amarras, sino mantener la posibilidad de reemprender más pronto o más tarde la negociación. carta particular Visconti-Tornielli, 1 de agosto, ibídem, págs. 107-109. 
La opinión francesa se manifestó contraria a un convenio y, en Italia, la prensa de oposición publicó vehementes manifestaciones de germanofilia. Con todo, la reacción no era tan estridente, pues nadie daba fe a que estuvieran negociando los dos gobiernos. El de Francia aguardaba los resultados de su orientación pacifista, tras su acercamiento y su pacto con Rusia. La prensa francesa estaba inquieta ante el posible regreso de Crispi, que supondría el regreso a una excesiva ostentación de la alianza con Alemania, sin esconder sus proyecto agresivos hacia Francia. ${ }^{137}$

Como hemos dicho antes, Visconti Venosta expuso a Bülow que, dado el carácter amistoso y personal de la visita al emperador, juzgaba preferible que no acompañaran al Rey los ministros si la estancia se limitaba a Hamburgo. Si pasara por Berlín, iría con Humberto I algún miembro del gabinete. Quería evitar que Guillermo II y sus ministros tuvieran la sensación de que se deseaba separar a los soberanos de sus gobiernos. ${ }^{138}$ La perspectiva desde Berlín era distinta. Estarían en Hambrugo Hohenlohe y Bülow. El emperador no conocía a Visconti Venosta. Eso hacía oportuna su presencia en Hamburgo. ${ }^{139}$ Así se acordó. ${ }^{140}$

Para la respuesta a Guillermo II en el previsible brindis del banquete del 4 de septiembre, se preparó un texto protocolario, breve, en el cual Humberto I manifestaba sus sentimientos de amigo sincero y de aliado fiel. ${ }^{141}$

Cuando se comunicó a París, ${ }^{142}$ Tornielli pensó que le faltaban apoyos para llevar a buen puerto su misión. ${ }^{143}$ ¿Podría Italia iniciar un camino nuevo cuando la situación europea estaba cargada de incertidumbres? El gobierno di Rudinì quería mantener los pactos existentes con los dos impe-

137 Aunque el tratado fuera claramente mejorable, conseguirlo supondría el comienzo de un nuevo estilo en las relaciones con Francia y tendría resultados positivos contra los especuladores en la Bolsa. Goluchowski, que visitó esos días París, dijo a Tornielli que la política exterior francesa no se modificaría con los cambios de gobierno. Carta particular Tornielli-Visconti, 7 de agosto, ibídem, págs. 116-118.

138 Carta particular Visconti-Lanza, 15 de agosto, ibídem, págs. 132-133.

139 Telegrama confidencial 2983 Lanza-Visconti, 20 de agosto, ibídem, pág. 142.

140 La reacción en Berlín, carta particular Lanza-Visconti, 24 de agosto, ibídem, pág. 146.

141 Carta particular Lanza-Visconti, 19 de agosto. El ministro quería que se omitiera la referencia a las circunstancias en que tuvo lugar la visita de Guillermo II a Venecia. Telegrama 2205 Visconti-Lanza, 25 de agosto, ibídem, págs. 141-142 y 148.

142 Telegrama 2225 Visconti-Tornielli, 27 de agosto, ibídem, pág. 151.

143 Pidió que le retiraran de París y que, aprovechando el reingreso de Ferrero en el ejército, lo trasladaran a Londres. Todas las dificultades las agravaba la opinión pública francesa. Había que tener sangre fría. Necesitaba el ministro que Tornielli siguiera en su puesto. Carta particular ViscontiTornieli, 30 de agosto en respuesta a Tornielli-Visconti, 26 de agosto, ibídem, págs. 153-154 y 150-151. Acuse de recibo, carta particular Tornielli-Visconti, 9 de septiembre, ibídem, pág. 156. Volvió a insistir en su traslado a Londres, Tornielli-Visconti, 24 de marzo de 1898, ibídem, pág. 299. 
rios centrales y con Inglaterra y mejorar sus relaciones con Francia y Rusia. Esa aspiración no era una quimera. Las dos alianza estaban actuando como sindicatos de intereses que apostaban por la paz. En Roma tenían la impresión de que el gobierno francés, entusiasmado por su alianza con los rusos, otorgaba escasa importancia a Italia. Pedían reciprocidad. Había que ser cautos. ${ }^{144}$ La previsión de Visconti se confirmó pronto. ${ }^{145}$ La negociación comercial se reemprendería en París una vez cerradas las Cámaras. ${ }^{146}$

\section{La necesidad de paz entre las potencias en 1898}

Después del viaje de Guillermo II a Rusia, parecía que Alemania, que creía en el valor de la Triple Alianza, haría una política paralela con Rusia, con la que no existía diferencias y que tenía buenas relaciones con Francia. Todo eso contribuía a la paz en Europa. ${ }^{147}$

En los brindis San Petersburgo, Felix Faure, presidente de la República Francesa, y Nicolás II pronunciaron la palabra "alianza". ${ }^{148} \mathrm{El}$ alcance de esta expresión no se comentó en las entrevistas entre los dos Emperadores. No importaba la forma en que se concretaran los compromisos entre rusos y franceses. Los alemanes estaban satisfechos porque los rusos querían la paz. Para Bülow, cuanto más íntimas fueran las relaciones franco-rusas mayor sería el peso del zar en la política de sus aliados. ${ }^{149}$

Hanotaux comentó que, en las conversaciones con Nicolás II y con Muravieff, habló de Italia. ${ }^{150}$ Expuso al zar las buenas disposiciones de

144 "Questa politica di riaviccinamento proseguita con calma e che potrà trovare le sue applicazioni nello svolgersi delle quistinoni europee varrà a rifare un ambiente favorevole per la pacificazione economica che ne dovrà essere il suggello". Carta particular Visconti-Tornielli, 17 de septiembre, ibídem, págs. 159-160. La necesidad de no romper la negociación, carta particular Tonielli-Visconti, 27 de septiembre, ibídem, págs. 168-169. La limitación que imponía al gobierno francés la Asamblea Nacional, telegrama 3508 Tornielli-Visconti, 20 de octubre, ibídem, pág. 187.

145 Al publicarse el Libro Verde sobre la posición del gobierno italiano en los asuntos de Creta, se vio la coincidencia con Francia. La buena impresión que provocó ese hecho desbloquearía la negociación comercial, según Hanotaux. Reservado 3681/1201 Tornielli-Visconti, 20 de diciembre, ibídem, pág. 231.

146 Confidencial 4042 Tornielli-Visconti, 23 de diciembre, ibídem, pág. 238.

147 Comentario del secretario de Estado para los Asuntos Exteriores, Bernhard Bülow. 1198/458 Lanza-Visconti, 16 de agosto, Documenti Diplomatici Italiani... Roma, 1958, pág. 134.

$148 \mathrm{El}$ entusiasmo francés por este acto, reservado 3062 Tornielli-Visconti, 30 de agosto, ibídem, pág. 153.

149 Confidencial 1256/475 Lanza-Visconti, 28 de agosto, ibídem, pág. 152.

150 Los dos gobiernos miraban con simpatía la "politica nostra attuale". Carta particular Tornielli-Visconti, 9 de septiembre, ibídem, págs. 156-158. Confirmaron esa impresión las palabras de Muravieff al encargado de negocios de Italia en San Petersburgo y las instrucciones para Alejandro 
Francia hacia España, subrayando "quel soin nous gardons de tout ce qui pouvait donner du souci à la Reine Régente, soit sur la frontière soit à l'intérieur, en paraissant favoriser les menées carlistes ou révolutionnaires". En este contexto hablaron Hanotaux y el conde Muraviewff sobre Marruecos. Este fue tajante en la promesa de solidaridad con su aliado. ${ }^{151}$ Esto inquietó a Italia. Rusia abrió una legación en Tánger. Era una señal de su voluntad de impulsar su acción en el Mediterráneo.

No era creíble que, con sus pactos con Francia, Rusia se hubiera dejado arrastrar a un compromiso contra Alemania, pero no lo era respecto a Inglaterra sobre todo en el Mediterráneo, donde Nicolás II deseaba estar presente y frenar la hegemonía inglesa en la zona.

En el envío a Roma de un diplomático con la experiencia de Nelidow, que estuvo antes en Constantinopla, "non sia stato del tutto straneo quel nuovo e vigoros impulso che il Gabinetto Imperiale intende dare alla sua azione nel Mediterraneo e che accanto al sincero desiderio di stabilire coll'Italia più intime e cordiali relazioni, esso sia stato pure ispirato dal proposito di promuovere possibelmente un nostro ravvicinamento alla Francia distaccandoci dall'Inghilterra". ${ }^{152}$

En San Petersburgo se guardaba absoluta reserva en torno al futuro de Bizerta. ${ }^{153}$ El Consejo Superior de la Marina, al que asistió el zar, se opuso a la creación de una base naval. ${ }^{154}$

Nelidow, nuevo embajador ruso en Roma. 603/330 y telegrama 3778 Melegari-Visconti, 17 y 18 de noviembre, ibídem, págs. 203-204. La reciprocidad de Italia, 44980/257 Visconti-Melegari, 2 de diciembre, ibídem, págs. 219-220. Así lo manifestó el encargado de negocios a Muravieff el 8 de dicembre, 646/356 Melegari-Visconti, 9 de diciembre, ibídem, pág. 226.

151 'Le Comte Mouravieff m'a dit qu'il avait obtenu de l'Empereur lui-même la création d'une agence, spécialment dans le but de favoriser et d'aider notre action contre celle de l'Angleterre et des puissances qui la secondent". "Voyage de M. Félix Faure en Russie (18-31 août 1897). Notes (de Gabriel Hanotaux) sur le voyage à Petersbourg. Entretiens avec l'Empererur et avec le Comte Mouravieff', Revue d'Histoire Diplomatique, 80, 1966, págs. 214-230. El marco de las relaciones entre los dos países desde 1891, Girault, René: Diplomatie européene et impérialismes 1871-1914, Paris, 1979, págs. 111-169.

152 718/379 Melegari-Visconti, 30 de diciembre. Salisbury se mostró escéptico y poco preocupado por la posible presencia de naves rusas en Bizerta. Pese a los temores de Crispi, nada pasó cuando los franceses ocuparon aquel puerto. 9/4 Ferrero-Visconti, 6 de enero de 1898, ibídem, págs. 242-245.

153 T 101 Morra di Lavriano-Visconti, 15 de enero, ibídem, pág. 255.

154 Reservado y confidencial 42/19 Morra di Lavriano-Visconti, 19 de enero, ibídem, pág. 257. Visconti fue interpelado en la Cámara sobre ese punto. Respondería que la noticia carecía de fundamento. Telegrama 239 Visconti-Tornielli y 265 Tornielli-Visconi 29 y 30 de enero, ibídem, pág. 264265. La cantidad gastada en el golfo de Bizerta no permitía concluir que fuera a construirse una gran base militar. Reservado 305/117 Tornielli-Visconti, 7 de febrero, ibídem, págs. 268-269. 
Ese otoño de 1897, en medio de una polémica en la prensa de Alemania e Inglaterra, Salisbury pronunció un discurso en el banquete anual del Lord Mayor de Londres. Afirmó que el Reino Unido no se aislaría. Cooperaría con las otras potencias en la solución de los problemas europeos. ${ }^{155}$

La entrevista de Goluchoscki en Monza con el Rey, el marqués di Rudinì y Visconti Venosta demostró la sintonía entre Viena y Roma en política exterior. Austria apoyó la aproximación de Italia a Francia. Había que superar la tensión entre Alemania e Inglaterra, ${ }^{156}$ para que esta no se alejase de los tres aliados y no se acercase a Francia y Rusia. ${ }^{157}$

Esos mismos días la presencia de naves rusas y alemanas en el Mar de la China removió a la opinión británica. ${ }^{158}$ La presión sobre el gobierno de Pekín podría desencadenar la anarquía. Esta situación hundiría el comercio inglés, ya amenazado con el progreso de las exportaciones alemanas, mientras descendían las inglesas. ${ }^{159}$

¿Había un acuerdo con los rusos para extender el comercio alemán por el Sur de China, perjudicando seriamente a los ingleses? Rusia quería, según Radolin, embajador alemán en San Petersburgo, convertir Vladivostok en un gran puerto militar. China le concedió Port Arthur para que invernaran sus naves, temiendo que Inglaterra diera un golpe de mano. Y esa decisión fue aprobada por Berlín, que comenzaba a sentir los efectos positivos que, de cara a una recuperación de las buenas relaciones entre los dos países, tenía esa situación en Londres. ${ }^{160}$

155 En Berlín gustó especialmente su tono pacífico. 1611/625 Lanza-Visconti, 11 de noviembre de 1897, Documenti Diplomatici Italiani... Roma, 1958, págs. 199-200.

156 Despacho de Goluchowski a los embajadores resumiendo los temas tratados. El embajador de Austria en Berlín, Ladislao Szögyényi-Marich, dio una copia a su colega italiano. Reservado 1672/653 Lanza-Visconti, 27 de noviembre, ibídem, págs. 215-216.

157 Las relaciones entre París y Londres mejoraban, a pesar de que la negociación sobre territorios africanos necesariamente iba despacio, por falta de mapas que permitieran un exacto conocimiento de aquellas regiones. Reservado Tornielli-Visconti, 22 de diciembre, ibídem, págs. 234-235.

158 Sobre la ocupación del puerto de Kian-Tschan y los preparativos militares alemanes ante un posible conflicto en Extremo Oriente, 665/368 Melegari-Visconti, 17 de diciembre. Transmitió un resumen a Berlín el subsecretario de Asuntos Exteriores. 48256/521 Bonin Longare-Lanza, 28 de diciembre.

Comentario sobre la postura inglesa, 17/12 Ferrero-Visconti, 11 de enero de 1898. La actitud de Bülow, confidencial 63/34 Lanza-Visconti, 19 de enero, ibídem, págs. 229-230, 242, 252-253 y 255-256. Kennedy, Paul: The Rise of Anglo-German antagonism, London, 1982. pág. 233.

159 808/391 Ferrero-Visconti, 21 de diciembre, Documenti Diplomatici Italiani... Roma, 1958

160 Manifestaciones reservadas de Radolin a Melegari. R. e conf. 714/377 Melegari-Visconti, 26 de diciembre, ibídem, pág. 340. 
Su política en aquellos mares se basaba en la superioridad naval frente a las otras escuadras reunidas y la estabilidad dentro del Imperio Chino, que, en caso de que se viera presionado por alemanes, rusos y franceses, buscaría la protección de los ingleses. Con problemas en la frontera de la India y una guerra en Sudán, ${ }^{161}$ el Reino Unido no entraría en un conflicto con las otras potencias, ni siquiera contando con la ayuda de Japón.

Rusia podría esperar su momento en China. Su posición geográfica le permitía jugar todas las baza para ganar. Japón necesitaba la paz y no repetiría su enfrentamiento con China. Francia y Rusia estaban satisfechas con lo conseguido en China. Estados Unidos también se beneficiaba del statu $q u o$. A Italia le convenía ganar tiempo, porque no estaba en condiciones de participar en un reparto colonial.

Siendo Inglaterra la única potencia no proteccionista en sus dominios y colonias, a todos favorecía su éxito. Así lo entendían los norteamericanos. ${ }^{162}$

Estas impresiones fueron ratificadas en el discurso de Balfour en Manchester: los intereses comerciales ingleses, mayores que los de todas las demás potencias, quedaban mejor amparados si se preservaba la existencia del Imperio chino y todos comerciaban allí libremente, sin zonas protegidas en beneficio de terceros. ${ }^{163}$

En este clima, las declaraciones de Bülow en la Cámara prusiana en defensa de la libertad de comercio contribuyeron a mejorar las relaciones con Inglaterra. ${ }^{164}$

Las circunstancias que afectan a las relaciones entre las potencias europeas, la orientación de la política norteamericana, la necesidad de mejorar las relaciones internacionales, mientras persistían los efectos de la ruptura del "concierto europeo" y Estados Unidos entraba en la escena

161 Las preocupaciones de Salisbury por la reacción del Negus, tras la victoria de Ondurman y el comienzo de una campaña decisiva en Sudán, 319/152 Ferrero-Visconti, 6 de mayo, ibídem, págs. 318-319. Un comentario a este despacho, 19788/159 Visconti-Ferrero, 28 de mayo, ibídem, págs. 331-332.

162 "È tuttavia da sperarsi che la politica di moderazione e di vigile aspettativa seguita finora da questo governo non debba essere modificata sensibilmente da questi avvenimenti e raggiuga il desiderato intento di salvare gli interessi britannici senza minaccia per la pace". 10/5 Ferrero-Visconti, 6 de enero de 1898, ibídem, págs. 245-247.

163 17/12 Ferrero-Visconti, 11 de enero. Salisbury hizo suyas las palabras del secretario de Colonias y apreció la prudencia de Francia. 24/17 Ferrero-Visconti, 13 de enero, ibídem, págs. 251-252 y 254.

164 Los alemanes estaban inquietos por el incremento de los barcos de guerra japoneses en el Mar de la China. Su embajador en Londres habló del asunto con Salisbury. 57/31 Ferrero-Visconti, 27 de enero, ibídem, pág. 264. 
internacional, el temor a la guerra y a la presión de la opinión de cada país si no se defendían los intereses nacionales, la crisis interna en China, derrotada y humillada por Japón, la descomposición del Imperio Otomano, la inestabilidad en Marruecos, tras la muerte de Muley Hassan, los problemas Francia e Inglaterra como potencias coloniales en África y en Asia... forman un conjunto que permite entender que el "aislamiento de España" esos años fue algo más que una opción de los gobiernos de la Restauración. A ese complejo de causas, habría que sumar el olvido de que para Cuba había llegado la hora de la emancipación. ${ }^{165}$

165 "Recuerdo haber leído no hace mucho tiempo, en un libro notable que unos pobres pescadores del Adriático, al doblar la punta de una isla desierta escucharon angustiosas voces y tristísimo sonido, que repetían sin cesar: el dios Pan ha muerto. Pues bien, señores: los viajeros que hoy salen de Europa y dirigen el rumbo al Asia o a las Américas, escuchan también en la dilatada extensión de los mares ecos, parecido a aquellos, que repiten: el sistema colonial ha muerto". Discurso de Ricardo Alzugaray en el debate sobre el abandono de Santo Domingo, Diario de las Sesiones de Cortes. Congreso de los Diputados 61 (28 de marzo de 1865), pág. 1603. 